INTER NATIONAL MONETARY FUND
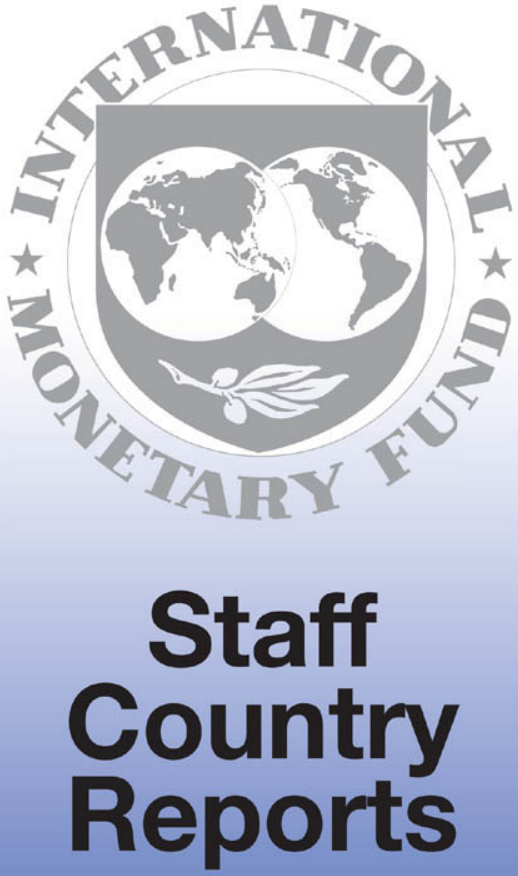


\title{
Republic of Poland: Financial Sector Assessment Program- Technical Note-Competition and Performance in the Polish Second Pillar
}

This Technical Note for the Republic of Poland on Competition and Performance in the Polish Second Pillar was prepared by a staff team of the International Monetary Fund as background documentation to the Financial Sector Assessment Program with the member country. It is based on the information available at the time it was completed in October 2006. The views expressed in this document are those of the staff team and do not necessarily reflect the views of the government of the Republic of Poland or the Executive Board of the IMF.

The policy of publication of staff reports and other documents by the IMF allows for the deletion of market-sensitive information.

To assist the IMF in evaluating the publication policy, reader comments are invited and may be sent by e-mail to publicationpolicy@imf.org.

\author{
Copies of this report are available to the public from \\ International Monetary Fund $\bullet$ Publication Services \\ 700 19th Street, N.W. • Washington, D.C. 20431 \\ Telephone: (202) 6237430 • Telefax: (202) 6237201 \\ E-mail: publications@imf.org • Internet: http://www.imf.org \\ Price: $\$ 18.00$ a copy

\section{International Monetary Fund Washington, D.C.}


This page intentionally left blank 


\title{
FinANCIAL SECTOR ASSESSMENT PROGRAM REPUBLIC OF POLAND
}

\author{
TECHNICAL NoTE
}

COMPETITION AND

PERFORMANCE IN THE

POLISH SECOND PILLAR

OCTOBER 2006

INTERNATIONAL MONETARY FUND MONETARY AND CAPITAL MARKETS DEPARTMENT
THE WORLD BANK FINANCIAL AND PRIVATE SECTOR DEVELOPMENT

VICE PRESIDENCY EUROPE AND CENTRAL ASIA REGION VICE PRESIDENCY 


\section{Contents}

I. Introduction

II. Overview of the Polish Pension System ........................................................... $\underline{5}$

A. The Polish Pension System after the 1998 Reform ........................................ $\underline{5}$

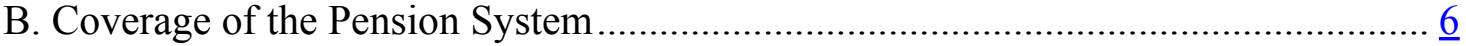

C. Fiscal Impact of the Pension Reform ............................................................. $\underline{8}$

III. Structure and Performance of the Second Pillar ...................................................... 11

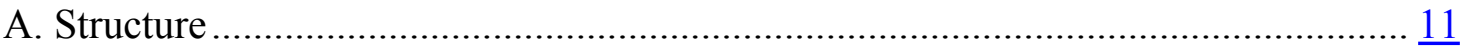

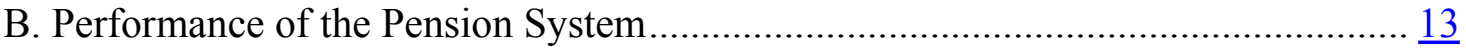

IV. Main Regulatory and Supervisory Issues …................................................ 28

A. An Overview of the Regulatory Framework..................................................... $\frac{28}{35}$

B. An Overview of the Supervisory Framework …........................................... $\underline{35}$

V. The Domestic Capital Market .......................................................................... $\underline{36}$

A. The Market for Government Debt ……....................................................... $\frac{36}{36}$

B. The Equity Market ................................................................................. $\frac{37}{38}$

C. Other Fixed-income Instruments.................................................................... 38

VI. Recommendations for Improving the Performance of the Second Pillar .................. $\underline{39}$

A. Recommendations for Improvements in the Accumulation Phase ........................ $\underline{39}$

B. Preparing the Regulatory Framework for the Payout Phase ............................... 43

C. Developing Financial Instruments for the Two Phases.................................... 47

Appendix I. An Analysis of Price Competition in the Pension Sector .......................... $\underline{52}$

Tables

Table 1. Coverage Ratios and Covered Wage Bill, 1999-2005 ................................... 7

Table 2. Selected Macroeconomic and Fiscal Indicators, 1999-2005 ............................. $\underline{9}$

Table 3. Number of Second Pillar Pension Funds in Latin America and Central Europe 11

Table 4. Market Structure in Poland's Second Pillar, 2005 ...................................... 11

Table 5. Pension Fund Assets, 1999-2005 ….......................................................... $\frac{13}{14}$

Table 6. Pension Assets in Poland and Other Reforming Countries ( $\%$ of GDP) ............ 14

Table 7. Pension Fund Portfolios (\% of total assets), 1999-2005 .................................. $\frac{15}{15}$

Table 8. Pension Fund Portfolios, Poland and Other Selected Countries ....................... $\frac{15}{16}$

Table 9. Characteristics of the Equity Portfolio of Polish Pension Funds ....................... $\frac{16}{16}$

Table 10. Pension Fund Returns, Inflation Rate, GDP Growth and Indexation of NDC $\underline{19}$

Table 11. Rates of Return of Second Pillar Pension Funds in Reforming Countries ....... $\frac{19}{23}$

Table 12. Operational Costs of Pension Funds in Selected Countries, 2005 .................. 23

Table 13. Projected Fees ........................................................................................ $\frac{26}{27}$

Table 14. Annual Nominal Return on Equity of Polish PTEs and Banks ...................... 27

Table 15. ROEs of Pension Fund Managers in Selected Countries (\% p.a.)................... 27

Table 16. Ceilings on Investment in Fixed-income Instruments ( $\%$ of total assets) ........ $\underline{32}$ 
Table 17. Design of the Minimum Return Guarantee in Poland and Other Countries..... $\underline{34}$

Table 18. Stocks and Holders of Financial Instruments, 2005 .................................. $\underline{36}$

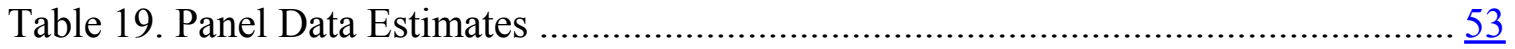

Figures

Figure 1. Coverage Ratio (\%) and Per Capita Income (US\$ PPP, 2000) ........................ 7

Figure 2. Covered Wage Bill (\% of GDP) and Per Capita Income (US\$ PPP, 2000)........ $\underline{8}$

Figure 3. Balance of the PAYG System (\% of GDP) ................................................ 10

Figure 4. Monthly Contributions to the Fully Funded System ..................................... $\frac{12}{12}$

Figure 5. Coefficient of Variation of the Equity Share in Pension Fund Portfolios......... 17

Figure 6. Coefficient of Variation of Equity Holdings, 2005 ..................................... 18

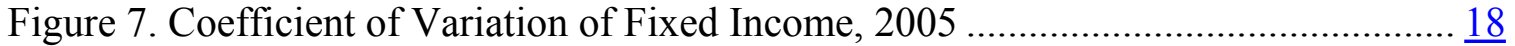

Figure 8. Poland Yield Curves (end of year) ..................................................... $\underline{20}$

Figure 9. Convergence of Returns of Polish Pension Funds ........................................ 21

Figure 10. Convergence of Returns of Chilean Pension Funds .................................... 21

Figure 11. Rates of Return of Polish Funds and the MRG ......................................... 21

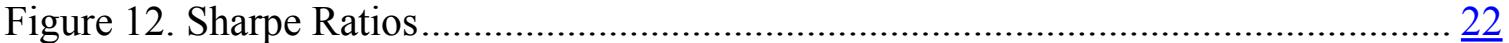

Figure 13. Modigliani Ratios (against WIG) ......................................................... $\frac{23}{24}$

Figure 14. Ceilings on Asset Management Fees (annualized marginal rates) .................. $\underline{24}$

Figure 15. Ratio of Total Fees over Assets in 2005 .................................................. 25

Figure 16. Total Fees over Assets, Poland and Other Countries $(\%)$............................. 26

Figure 17. Return on Equity of PTEs (\%), 2002-2005 ................................................. 28

Figure 18. Duration of Government Bonds by Holder ............................................. $\frac{37}{52}$

Figure A1. Sharpe Ratios and Growth in Market Shares........................................... $\frac{52}{53}$

Figure A2. Quarterly Switchovers and OFE's Rate of Return $(\mathrm{t}-1)$............................... $\underline{53}$ 


\section{Glossary of Terms}

$\begin{array}{ll}\begin{array}{l}\text { Coverage Ratio } \\ \text { Covered Wage Bill }\end{array} & \begin{array}{l}\text { Number of contributors over labor force } \\ \text { Total contributions over contribution rate } \\ \text { DB }\end{array} \\ \text { FSAP } & \text { Financial Sector Assessment Program } \\ \text { KDPW } & \text { National Depository of Securities } \\ & \text { Insurance and Pension Funds Supervisory } \\ \text { KNUiFE } & \text { Commission } \\ \text { KPWIG } & \text { Securities and Exchange Commission } \\ \text { MBS } & \text { Mortgage-backed Securities } \\ \text { MRG } & \text { Minimum Return Guarantee } \\ \text { NBP } & \text { National Bank of Poland } \\ \text { NDC } & \text { Notional Defined Contribution System } \\ \text { OFE } & \text { Open Pension Fund } \\ \text { OTC } & \text { Over-the-Counter } \\ \text { PAYG } & \text { Pay-as-you-go system } \\ \text { PTE } & \text { Pension Fund Manager } \\ \text { SME } & \text { Small and Medium Enterprise } \\ \text { SPV } & \text { Special Purpose Vehicle } \\ \text { WIG } & \text { Warsaw General Stock Price Index } \\ \text { ZUS } & \text { Social Security Institution }\end{array}$




\section{INTRODUCTION ${ }^{1}$}

1. In March 1999, Poland implemented a systemic pension reform that involved the introduction of a multi-pillar pension system to replace the defined benefit (DB), pay-as-you-go (PAYG) system that had been operating since 1949. The new system includes a minimum pension guarantee (the zero pillar); a publicly managed, notional defined contribution (NDC) system (the first pillar); a privately managed, fully funded system (the second pillar), and a complementary fully funded system also operated by the private sector (the third pillar).

2. The new second pillar has grown significantly since its introduction in 1999, and has performed generally well. By 2005 more than 70 percent of active contributors were already enrolled in the second pillar, or the equivalent of more than half of the labor force. Pension fund assets have also grown significantly, accounting for about 9 percent of GDP and 10 percent of total financial assets in the same year. The young pension system has performed generally well by comparison with most other reforming countries. The central revenue collection system experienced difficulties in the early years of operation but has generated scale economies and contributed to the comparatively low levels of costs and fees in Poland. Returns have also been attractive, due to the capital gains generated by the decline in interest rates and also a buoyant equity market.

3. Despite the promising start, Polish-makers still need to address a number of challenges, to ensure that the young pension system continues to perform well and meets its objectives. Competition policies may need to be reviewed, in particular the combination of measures to maintain small pension funds operating while imposing strict caps on fees. Portfolios need to be more diversified, through changes in the investment regime and efforts to develop domestic financial instruments. Internal risk management practices need to be strengthened. Finally, the regulatory framework for the payout phase needs to be elaborated.

4. This technical note on the pension sector was elaborated as part of the Poland FSAP Update that took place in April-May 2006. The note assesses the structure and performance of the second pillar, as well as its regulatory and supervisory framework. The note is structured as follows. Section II provides an overview of the whole pension system after the 1999 reform, including coverage and fiscal policy in the transition to the new system. Section III analyses the structure and performance of the second pillar, including asset growth, portfolio composition, investment returns, and fees. Section IV examines the regulatory and supervisory framework for the second pillar. Section V analyzes briefly the status of capital market development and the main obstacles to the further development of financial instruments suitable to pension funds. Finally, Section VI provides a number of policy recommendations.

\footnotetext{
${ }^{1}$ This Technical Note was prepared by Heinz Rudolph and Roberto Rocha (OPD), as part of the Poland FSAP Update. Diego Sourrouille (OPD) provided research assistance.
} 


\section{Overview of the Polish Pension System}

\section{A. The Polish Pension System after the 1999 Reform $^{2}$}

5. In 1998, the Polish Parliament approved a systemic pension reform that involved the replacement of a traditional DB scheme operated by the public sector and financed on a PAYG basis by a new multi-pillar system. The reform was implemented in 1999, making Poland the second Central European country that implemented a systemic reform, following the Hungarian reform of 1997/1998. As in the case of Hungary and other reforming countries, the Polish reform was motivated by several objectives, including the need to restore actuarial balance, diversify risks for all the parties, and improve economic incentives.

6. The new pension system contains four pillars, including a minimum pension guarantee (the zero pillar), a new publicly managed system based on NDC accounts (the first pillar), a new private and fully funded system (the second pillar), and a voluntary and complementary fully funded system (the third pillar). In addition, the pension system also includes special regimes for farmers and security personnel. Participation in the new pension system was mandatory for all workers under 30 years of age. Workers between 30 and 50 years of age had to participate in the new NDC system but had the option to participate in the second pillar. Workers above 50 years of age had to stay in the old system. The retirement age ( 60 for women and 65 for men) and the total contribution rate were left unchanged. All workers contribute 19.52 percent of their gross wages to old age pensions, 13 percent to disability and survivorship insurance and 2.45 percent for sickness insurance. In the case of workers enrolled in the mixed system the contribution rate to old age pensions is split, with 12.22 percent going to the first pillar and 7.3 percent to the second pillar.

7. The new pension system was designed to be financially sustainable in the long-run, while also providing adequate pensions. The zero pillar provides a minimum pension that has been set at around 25 percent of the economy-wide average wage. The new NDC first pillar is expected to stabilize expenditures and deficits, as individual balances are indexed to the growth of the wage bill (the revenue base) and benefits are defined by the final notional balance and life expectancy. The first and second pillars should generate a replacement ratio of 60 percent for average income, full career workers. This is lower than the replacement ratio in the old system but seems sustainable and is in line with the average replacement ratio in the OECD. ${ }^{3}$

8. The new second pillar has been structured along the lines of the Chilean private pension system, but with some important changes such as a central revenue collection agency (ZUS). The second pillar operates on a defined contribution basis and involves individual accounts in open pension funds (OFEs) managed by dedicated private pension fund management companies (PTEs). Final benefits in the second pillar will depend on the accumulated contributions, investment returns and fees. There is also a

\footnotetext{
${ }^{2}$ This section draws on Chlon, Góra and Rutkowski (1999), Hausner (2001), and Chlon (2005).

${ }^{3}$ OECD (2005).
} 
third pillar that consists of individual pension accounts and occupational pension. The government provides limited tax incentives for individuals saving voluntarily for retirement (exemption from capital gains tax).

9. Poland also maintains special regimes for farmers and government personnel in the areas of public defense and security. Some additional groups have gained special concessions, setting a precedent and posing risks to the pension reform. The farmers' pension system is highly subsidized, as contributions only cover 6 percent of expenses. The regime for public defense and security workers (e.g., military, police, firefighters, border guards, and judiciary) is fully financed from the state budget. A special law approved in 2005 allowed miners to be removed from the general pension system and gain access to early retirement benefits according to pre-reform rules. Other special groups such as teachers, pilots, and train operators have also demanded similar privileges. The concession of exceptions and privileges to these groups poses risks to the 1998 reform.

\section{B. Coverage of the Pension System}

10. Coverage in Poland is relatively high by international comparison and in line with other leading Central European countries. As shown in Table 1 and Figure 1, Poland's coverage ratio is around 75 percent of the labor force, slightly above the international regression line and comparable to neighbor countries. Coverage has proved closely related to the level of development (measured by the level of per capita income) and success in dealing with the informality of labor markets and its complex causes. The middle income countries above the regression line are primarily Central European countries that inherited high coverage ratios from the former socialist regime, while the middle income countries below the regression line are primarily countries in Latin America and other regions outside Europe, that have historically struggled with informality.

\section{The covered wage bill (the effective contribution base) is also high by} international comparison, although it has declined and is somewhat low relative to neighbor countries. As shown in Table 1, the covered wage bill (obtained by dividing total contributions by the total contribution rate) declined slightly to 25 percent of GDP during the first half of the decade. It is still above the international regression line (Figure 2) and similar to Hungary's, but lower than those in the Czech Republic and Slovakia (around 33 percent of GDP) and Slovenia (around 40 percent of GDP). The recent decline can be partly explained by the relatively low growth of wages relative to GDP and the high levels of unemployment. The available data does not allow an examination of whether the decline also reflects efforts by the self-employed and other groups to reduce contribution liabilities by contributing at the minimum. ${ }^{4}$ In any case, the covered

\footnotetext{
${ }^{4}$ The imposition of a contribution ceiling (of 2.5 times the average wage) by the 1999 reform reduced the covered wage bill, but this decline probably took place in 1999.
} 
wage bill is an important policy variable that needs to be closely monitored by policymakers. ${ }^{5}$

Table 1. Coverage Ratios and Covered Wage Bill, 1999-2005

\begin{tabular}{|c|c|c|c|c|c|c|c|c|}
\hline \multirow[t]{2}{*}{ Year } & \multicolumn{2}{|c|}{$\begin{array}{l}\text { Contributions } \\
\text { (\% of GDP) }\end{array}$} & \multicolumn{2}{|c|}{$\begin{array}{c}\text { Contributors } \\
(1,000)\end{array}$} & \multirow{2}{*}{$\begin{array}{c}\text { Labor Force } \\
(1,000) \\
\\
(5)\end{array}$} & \multirow{2}{*}{$\begin{array}{c}\begin{array}{c}\text { Coverage } \\
\text { Ratio } \\
(\%)\end{array} \\
(3) /(5)\end{array}$} & \multirow{2}{*}{$\begin{array}{c}\begin{array}{c}\text { Pillar II } \\
\text { Coverage } \\
(\%)\end{array} \\
(4) /(3) \\
\end{array}$} & \multirow{2}{*}{$\begin{array}{c}\text { Covered } \\
\text { Wage Bill } \\
(\% \text { of GDP) } \\
\\
(1+2) / \text { rate }\end{array}$} \\
\hline & $\begin{array}{l}\text { ZUS } \\
(1)\end{array}$ & $\begin{array}{l}\text { OFEs } \\
(2)\end{array}$ & $\begin{array}{l}\text { General } \\
\text { (3) }\end{array}$ & $\begin{array}{l}\text { OFEs }^{1} \\
(4)\end{array}$ & & & & \\
\hline 1999 & 10.4 & 0.4 & 13,270 & 7,457 & 17,214 & & 56.2 & 29.2 \\
\hline 2000 & 9.2 & 1.1 & 13,059 & 8,617 & 17,300 & 75.5 & 66.0 & 27.8 \\
\hline 2001 & 9.3 & 1.2 & 12,851 & 8,595 & 17,229 & 74.6 & 66.9 & 28.4 \\
\hline 2002 & 8.8 & 1.2 & 12,761 & 8,625 & 17,097 & 74.6 & 67.6 & 27.3 \\
\hline 2003 & 8.3 & 1.2 & 12,739 & 8,705 & 16,991 & 75.0 & 68.3 & 25.9 \\
\hline 2004 & 8.0 & 1.1 & 12,857 & 9,003 & 17,139 & 75.0 & 70.0 & 24.9 \\
\hline 2005 & 8.0 & 1.3 & 13,130 & 9,215 & 17,283 & 76.0 & 70.2 & 25.1 \\
\hline
\end{tabular}

Notes: (1) At least one contribution during the year; Source: Ministry of Labor and Social Security.

Figure 1. Coverage Ratio (\%) and Per Capita Income (US\$ PPP, 2000)

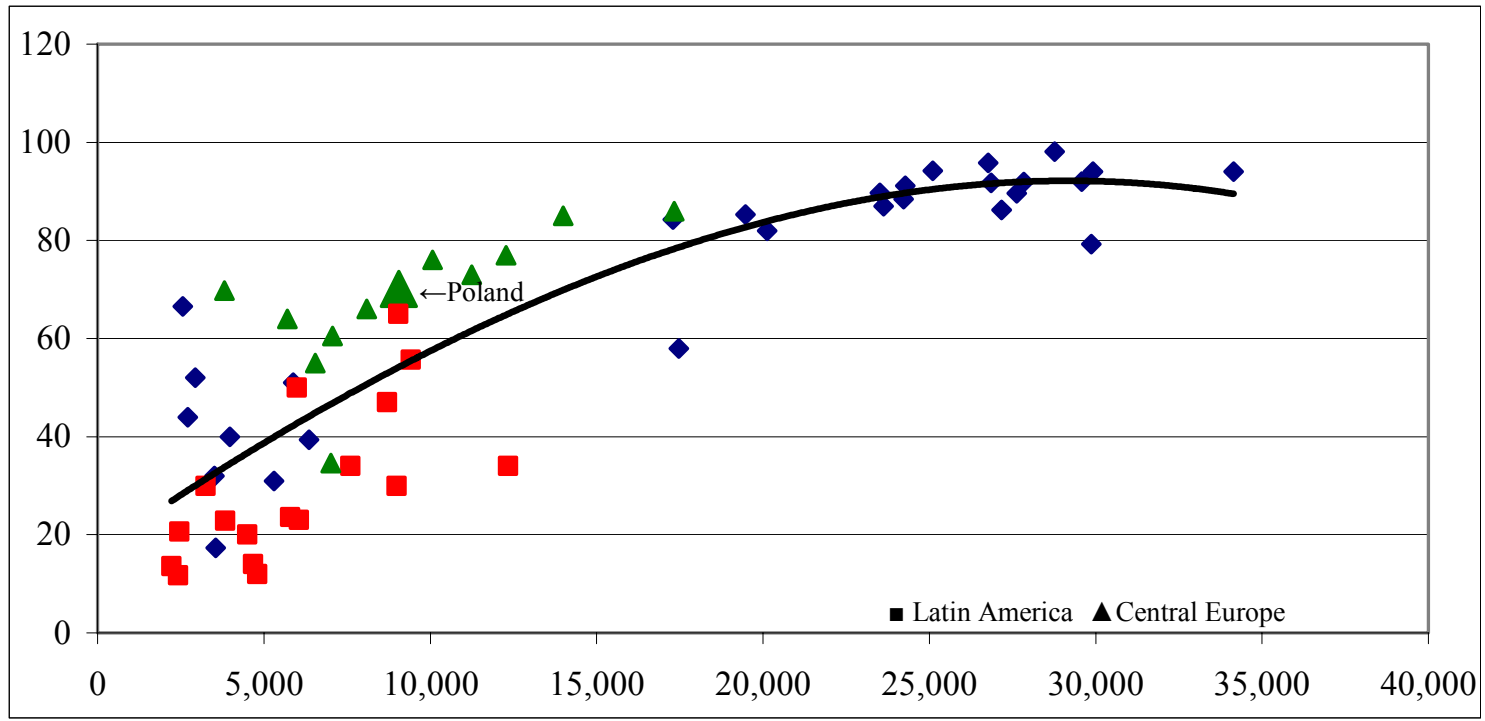

\footnotetext{
${ }^{5}$ Palacios and Rocha (1998) and Rocha and Vittas (2002) provide a detailed analysis of contribution revenues and the covered wage bill in Hungary before and after the 1997 pension reform.
} 
Figure 2. Covered Wage Bill (\% of GDP) and Per Capita Income (US\$ PPP, 2000)

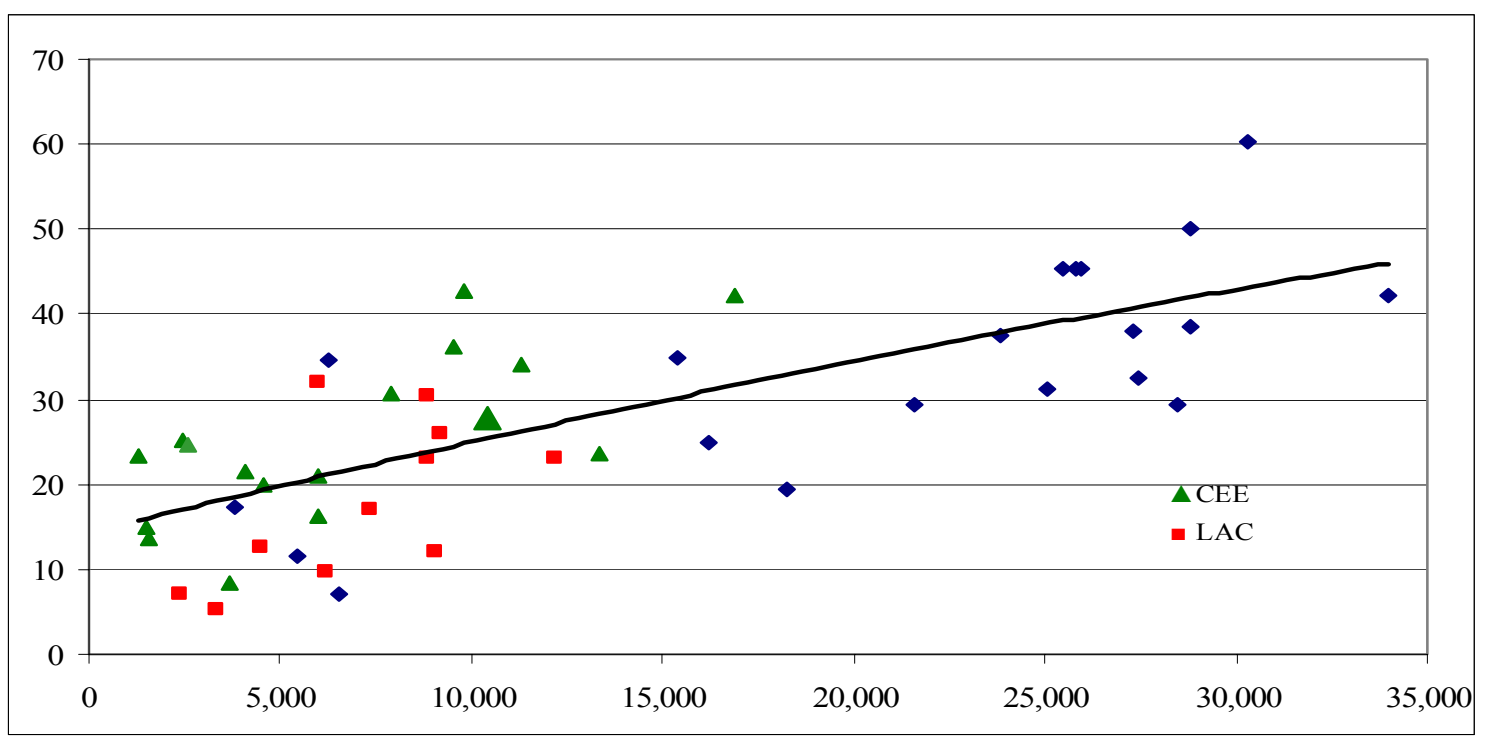

Sources: Staff estimates based on national sources.

12. The transition to the new system is already advanced, as indicated by 9.2 million active contributors to the second pillar, the equivalent of 70 percent of total contributors and more than half of the labor force. The share of active contributors enrolled in the new system has increased continuously as result of new entrants to the new system and the withdrawal of retiring workers from the old system. The flow of contributions to the second pillar has increased slowly but steadily, reaching about 1.3 percent of GDP in 2005, as shown in Table 1.

\section{Fiscal Impact of the Pension Reform}

13. A critical issue in pension reform relates to the strategy adopted for financing the transition to the new system. A tax-financed transition requires offsetting the fiscal losses caused by the introduction of the second pillar through tax increases or expenditure cuts. It burdens current generations temporarily but leads to an increase in domestic savings and higher growth performance that benefits all generations. A debtfinanced transition involves maintaining the balance of other taxes and expenditures constant and financing the fiscal losses caused by the second pillar through additional debt issues. Under certain assumptions savings ratios may remain stable but the explicit public debt increases and the burden of pension imbalances continues to be shifted to future generations. The optimal financing strategy is probably a mixed one, involving more debt finance in the early stages of the transition and more tax finance in later stages. $^{6}$

\footnotetext{
${ }^{6}$ See, e.g., Kotlikoff (1995 and 1996) for simulations of different financing strategies with the overlapping generations model. Corbo and Schmidt-Hebbel (2003) show that Chile was able to achieve very high growth rates after the reform due in part to a tax-financed transition.
} 
14. The transition to the new pension system was accompanied by an increase in the fiscal deficit that exceeded the fiscal losses caused by the second pillar. The fiscal deficit in Poland deteriorated significantly in the early phase of the reform, even controlling for the fiscal losses caused by the second pillar. As shown in Table 2, between 1999 and 2003 the general government deficit defined so as to neutralize the losses increased from 1.5 to 4.7 percent of GDP. The general government defined so as to reflect all the losses increased from 1.8 to 6.4 percent of GDP in the same period. The differences between the two sets of numbers reflect simply the inclusion or exclusion of second pillar funds in the definition of the general government. Essentially, they reflect the combined effect of the diversion of contributions to the second pillar (a revenue loss to the government), the returns on pension fund assets (a cost to the government) ${ }^{7}$, and the operating costs of the pension funds.

\section{Therefore, the transition in Poland has been fully debt-financed and} accompanied by an additional fiscal deterioration above and beyond the fiscal effects of the second pillar. This fiscal policy has contributed to lower savings rates and weakened the potential capital market effects of the reforms. The increase in the fiscal deficit (excluding the effects of the reform) by 3 percent of GDP between 1999 and 2003 contributed to the 2 percent decline in national savings during the same period and to the rapid increase in the levels of public debt, from 36 to 48 percent of GDP. There may be a false impression that the increase in public debt was due to exclusively to the pension reform, as the fiscal costs of the reform have also been estimated at about 12 percent of GDP. However, the ratio of debt to GDP declines with GDP growth and would have increased by a much smaller magnitude if the government had maintained the deficit (excluding the effects of the reform) at about 1.5 percent of GDP.

Table 2. Selected Macroeconomic and Fiscal Indicators, 1999-2005

\begin{tabular}{c|cccccc}
\hline \multirow{2}{*}{ Year } & & $\begin{array}{c}\text { Gross } \\
\text { Domestic } \\
\text { Saving }\end{array}$ & \multicolumn{5}{c}{ General Government (\% GDP) } \\
\cline { 2 - 7 } & $\begin{array}{c}\text { GDP growth } \\
(\%)\end{array}$ & $\begin{array}{c}\text { Debt resulting } \\
\text { from the } \\
\text { (\% GD) }\end{array}$ & Debt & $\begin{array}{c}\text { Pension Reform } \\
\text { Balance }\end{array}$ & BSA95(a) & $\begin{array}{c}\text { Balance } \\
\text { ESA95(b) }\end{array}$ \\
\hline 1999 & $(1)$ & $(2)$ & $(3)$ & $(4)$ & $(5)$ & $(6)$ \\
2000 & 4.1 & - & - & 0.7 & -1.5 & -1.8 \\
2001 & 4.0 & 18.7 & 36.9 & 2.5 & -1.8 & -2.8 \\
2002 & 1.1 & 18.0 & 38.8 & 4.6 & -3.7 & -4.8 \\
2003 & 1.4 & 16.1 & 43.6 & 6.6 & -3.2 & -5.0 \\
2004 & 3.8 & 16.6 & 48.5 & 8.7 & -4.7 & -6.4 \\
2005 & 5.3 & 16.2 & 46.9 & 10.5 & -3.8 & -5.6 \\
\hline
\end{tabular}

Notes: (a) OFEs inside the General Government; (b) OFEs outside the General Government. Sources: MoF, IMF.

16. There has been an improvement in the fiscal situation in recent years, and this improvement is expected to continue, as the effects of the pension reform materialize and the country makes efforts to meet the requirements for entry into

\footnotetext{
${ }^{7}$ This reflects the government's funding cost.
} 
the Euro zone. Fiscal deficits have declined by about 2 percent in the last two years, contributing to some recovery of domestic savings. Deficits should decline further in the future, due in part to projected improvements in the balance of the general PAYG system. As shown in Figure 3, general PAYG system should get close to equilibrium by the year 2014. Pension expenditures of PAYG system are projected to decline from around 10.6 percent of GDP in 2004 to 8.1 percent of GDP by 2014 as a result of expected increases in the effective retirement age, price-indexation of benefits, and an expected reduction in the number of disability pensioners. These reductions in expenditures should lead to commensurate declines in the PAYG deficit and in the overall fiscal deficit. ${ }^{8}$

17. Moving towards a more tax-financed transition will enhance the prospects of a stronger resumption of investment and output through stronger savings and capital market effects of the reform. It will also ensure a more fair distribution of the burden of the pension reform across generations. The potential savings and capital market effects of a pension reform depend fundamentally on the strategy for financing the transition and are closely related and mutually reinforcing. A reduction in the fiscal deficit would open more space for private investment, larger issues of new financial instruments by private companies and a more accelerated development of the domestic capital market, with mutually reinforcing effects. A reduction in the deficit would also avoid overburdening younger generations with excessive taxes, as these generations will already need to cope with lower benefits and replacement ratios relative to the ones enjoyed by current generations. ${ }^{9}$

Figure 3: Balance of the PAYG System (\% of GDP)

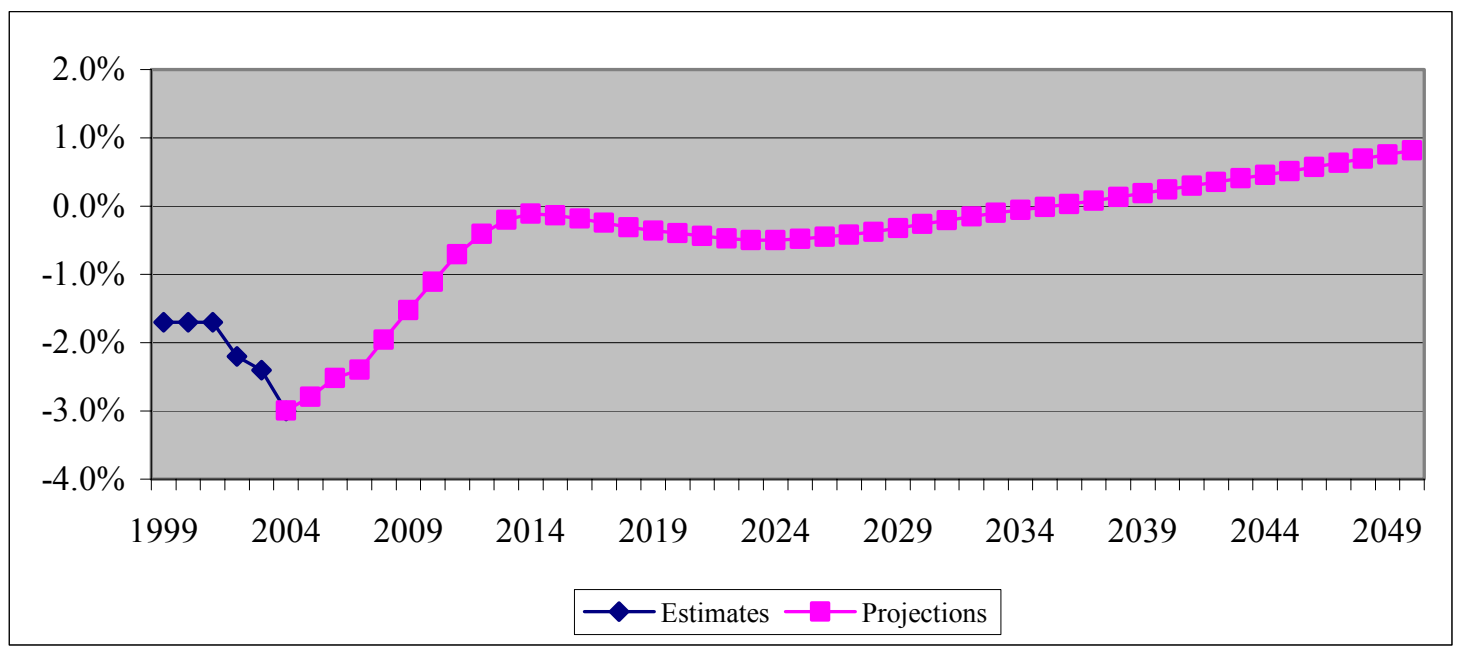

Source: Ministry of Labor and Social Security (projections), IMF (estimates).

Figures excludes second pillar, Farmers' Pension System and Security Provision System Base.

\footnotetext{
${ }^{8}$ See Ministry of Labor and Social Policy (2006) and IMF (2005).

${ }^{9}$ Gal, Simonovits, and Tarcali (2002) conduct an exercise of generational accounts for Hungary showing that the 1997 reform reduced the initial bias against future generations but did not remove it entirely.
} 


\section{Structure and Performance of the Second Pillar}

\section{A. Structure}

18. The pension fund sector is relatively concentrated and further consolidation may be expected. The number of pension funds has declined from 21 in 1999 to 15 in 2005, as a result of mergers among PTEs. The number of funds operating in the second pillar is still twice higher than the average of other countries, as shown in Table 3, but the second pillar in Poland has become as concentrated as the second pillars in other reforming countries. As shown in Table 4, the three largest pension funds account for 64 percent of total assets of the system, a ratio that is not too different from Chile's, where the three largest pension funds have 73 percent of the market. The main difference is that in Poland the small institutions have managed to survive, while in Chile the small institutions have already merged or left the market. In Poland the five smallest pension funds account for only 8.4 percent of the market and the smallest pension fund account for less than 1 percent. In recent months, some pension funds have requested authorization to merge and resolution by KNUiFE is pending.

Table 3. Number of Pension Funds in Latin America and Central Europe, 2005

\begin{tabular}{lc|lc}
\hline & Latin America & \multicolumn{2}{c}{ Central Europe } \\
\hline Argentina & 12 & Bulgaria & 8 \\
Bolivia & 2 & Croatia & 4 \\
Chile & 6 & Estonia (1) & 6 \\
Colombia & 6 & Hungary & 18 \\
Costa Rica & 8 & Kazakhstan & 14 \\
El Salvador & 2 & Latvia & 6 \\
Mexico & 13 & Poland & $\mathbf{1 5}$ \\
Peru & 4 & & $\mathbf{8}$ \\
Uruguay & 4 & Overall Average &
\end{tabular}

Sources: AIOS, FIAP.

Table 4. Market Structure in Poland's Second Pillar, 2005

\begin{tabular}{l|cc}
\hline & $\begin{array}{c}\text { Assets } \\
\text { (ZL million) }\end{array}$ & $\begin{array}{c}\text { Members } \\
\text { (thousand) }\end{array}$ \\
\hline Smallest pension fund & 752 & 235 \\
Largest pension fund & 23,458 & 2,563 \\
Average pension fund & 5,739 & 781 \\
Market Total & 86,079 & 11,720 \\
Share of largest three OFE & $63.7 \%$ & $56.3 \%$ \\
Share of smallest five OFE & $8.4 \%$ & $12.4 \%$ \\
\hline
\end{tabular}

Source: KNUiFE.

19. The pension fund sector has ownership links with the insurance sector and is largely operated by foreign companies. The seven largest pension funds are controlled by insurance companies, and three PTEs are controlled by banks. There are also two 
PTEs whose controller companies are not linked to active financial sector holding groups. The share of foreign ownership is high with most of the PTEs controlled directly or indirectly by international groups, including AIG, ING, Aviva, Allianz and Winterthur. Among the larger pension funds, PZU is the only PTE controlled by a domestic insurance company.

20. The Social Security Institution (ZUS) centralizes the collection of revenues for all social security contributions, including the first and second pillars. ZUS also pays social security benefits, including old age pension insurance, disability and survivorship insurance, sickness insurance, and work accident insurance. ZUS has to distribute the contributions to the second pillar among different pension funds, in the course of two weeks from the moment in which payments are received. ${ }^{10}$ All companies with more than five employees have to submit their contributions electronically, representing roughly 75 percent of the labor force and 95 percent of total contributions.

21. The centralized collection of revenues allows cost reductions through scale economies, but the monthly flows of contributions seem to be very volatile. As shown in Figure 4 the monthly flows of contributions are volatile, even when averaged for two consecutive months, and the volatility has increased since 2003 . This may be due to the calendar of pension payments, which reduces the predictability of contributions, but IT problems cannot be discarded. ${ }^{11}$

Figure 4. Monthly Contributions to the Fully Funded System

(two-month moving average)

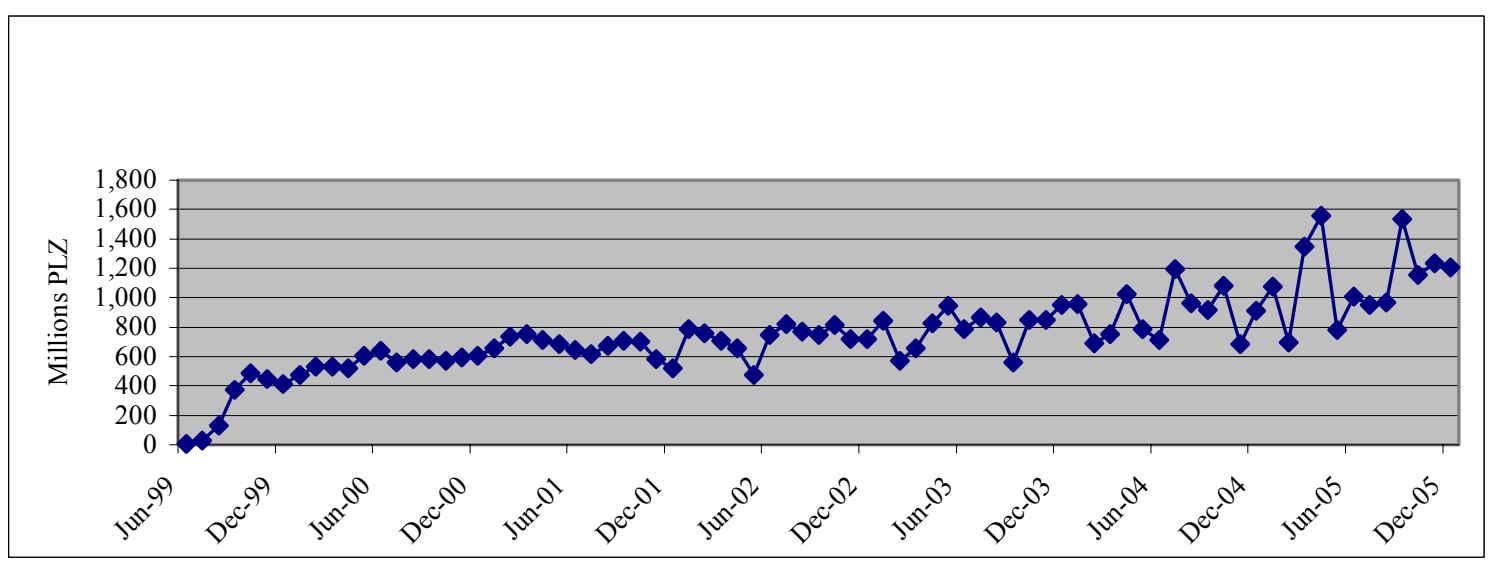

Source: ZUS.

22. Most PTEs outsource account management to separate management companies within the financial group. There are eight management companies (called

\footnotetext{
${ }^{10}$ In the initial stages of the system, there were severe problems with ZUS's collection and distribution systems. These problems seem to have been reasonably addressed. Currently less than 1 percent of the contributions have a problem of conciliation, although there are still PLN 1 billion from the 1999-2001 period that need to be cleared and allocated to individual accounts.

${ }^{11}$ We were unable to assess whether the volatility is a consequence of the calendar payments or any characteristic of ZUS's IT systems.
} 
transfer agents) that manage the individual accounts of PTEs, of which seven are related to the financial group of the PTE. Only four PTEs manage their accounts internally. The average cost of account management services is about USD 3.6 per member per year, which seems to be competitive by international standards, especially considering that this fee usually covers a number of services such as data processing, communication with clients, processing of new contracts and call centers. Since contracts with transfer agents are not standardized and may include differences in scope and quality of services, it is not possible to make comparisons across PTEs.

23. All securities have to be deposited at the National Depository of Securities (KDPW) and all domestic transactions have to be authorized by a custodian bank. Custodian banks also provide services of asset valuation. There are six custodian banks in Poland. Each PTE has to select a custodian bank that cannot be related to the company. The use of KDPW and custodian banks contributes to the containment of operational risks.

\section{B. Performance of the Pension System}

\section{Asset Accumulation}

24. Pension funds have grown steadily since the start of the reform and have become one of the most important institutional investors in the country. The ratio of pension assets to GDP compares well with the average of other reforming countries. Pension fund assets reached 9 percent of GDP in 2005, accounting for more than 10 percent of the financial sector, as shown in Table 5. The ratio of pension assets to GDP in Poland is higher than the ratios of most other countries with the same period of implementation, as shown in Table 6. The relatively faster growth of pension assets in Poland is partly explained by the comparatively higher covered wage bill, as discussed in the previous section, but is also due to relatively good returns and success in controlling fees, as examined below.

Table 5. Pension Fund Assets, 1999-2005

\begin{tabular}{ccccccc}
\hline 1999 & 2000 & 2001 & 2002 & 2003 & 2004 & 2005 \\
\hline \multicolumn{7}{c}{ Millions of US Dollars } \\
544 & 2,396 & 4,869 & 8,223 & 11,986 & 20,943 & 26,396 \\
0.3 & 1.3 & $\begin{array}{c}2.5 \\
\text { \% of GDP }\end{array}$ & $\begin{array}{c}3.9 \\
\text { \% of Financial Sector Assets }\end{array}$ & 5.3 & 8.8 & 8.9 \\
1.0 & 2.1 & - & 5.4 & - & 8.6 & 10.3 \\
\hline
\end{tabular}

Sources: KNUiFE, NBP. 
Table 6. Pension Assets in Poland and Other Reforming Countries (\% of GDP)

\begin{tabular}{l|ccc}
\hline Country & $\begin{array}{c}\text { First Year of } \\
\text { Operation }\end{array}$ & $\begin{array}{c}\text { At 7th Year of } \\
\text { Operation }\end{array}$ & 2005 \\
\hline Argentina & 1994 & 7.1 & 12.9 \\
Bolivia & 1997 & 20.9 & 21.6 \\
Chile & 1981 & 13.5 & 59.4 \\
Colombia & 1994 & 4.6 & 17.2 \\
Costa Rica & 2001 & - & 3.7 \\
El Salvador & 1998 & 13.7 & 18.3 \\
Hungary & 1998 & 4.0 & 5.6 \\
Mexico & 1997 & 5.7 & 7.0 \\
Peru & 1993 & 4.1 & 12.1 \\
Poland & $\mathbf{1 9 9 9}$ & $\mathbf{8 . 9}$ & $\mathbf{8 . 9}$ \\
Uruguay & 1996 & 9.3 & 15.3 \\
\hline Sout AIOS, KNU
\end{tabular}

Source: AIOS, KNUiFE.

\section{Portfolio Composition}

25. The portfolios of Polish pension funds are not very well diversified, a situation that is similar to most other reforming countries. At the same time, there are some noticeable differences with other countries, such as larger holdings of domestic equity and smaller investments in privately issued fixed-income instruments. As shown in Table 7, the portfolio composition of Polish funds has been relatively stable over time, with about 63 percent in government securities, 32 percent in domestic equity and negligible investments in other instruments. The large share of government bonds in pension portfolios is also observed in other countries, as shown in Table 8 . At the same time, there are some noticeable differences, such as the high share of domestic equity and the small share of fixed-income instruments. The low share of foreign assets also contrasts with the portfolios of more advanced reforming countries. It is also noteworthy that derivatives are not allowed, while in most of the advanced reforming countries these instruments are already allowed for hedging purposes. ${ }^{12}$

\footnotetext{
12 The permission for pension funds to use derivatives admittedly varies across countries, but simple derivatives such as currency forwards and swaps are allowed in many countries for hedging purposes, especially when pension funds start investing abroad.
} 
Table 7. Pension Fund Portfolios (\% of total assets), 1999-2005

\begin{tabular}{cccccccc}
\hline & $\begin{array}{c}\text { Government } \\
\text { Instruments }\end{array}$ & $\begin{array}{c}\text { Bank } \\
\text { Securities } \\
\text { and Deposits }\end{array}$ & Equity & $\begin{array}{c}\text { Other } \\
\text { Fixed } \\
\text { Income }\end{array}$ & Foreign & Others & Total \\
\hline 1999 & 53.2 & 2.1 & 29.9 & 14.9 & 0.0 & 0.0 & 100.0 \\
2000 & 62.8 & 2.1 & 34.9 & 0.2 & 0.0 & 0.0 & 100.0 \\
2001 & 67.1 & 2.8 & 28.3 & 1.4 & 0.4 & 0.0 & 100.0 \\
2002 & 67.9 & 2.6 & 27.1 & 1.0 & 1.4 & 0.0 & 100.0 \\
2003 & 61.6 & 3.9 & 32.0 & 0.8 & 1.5 & 0.2 & 100.0 \\
2004 & 59.4 & 4.5 & 32.8 & 0.6 & 2.2 & 0.5 & 100.0 \\
2005 & 62.5 & 3.4 & 31.4 & 0.5 & 1.7 & 0.4 & 100.0 \\
\hline
\end{tabular}

Note: Figures are as end of December of each year.

Source: KNUiFE.

Table 8. Pension Fund Portfolios, Poland and Other Selected Countries, December $2005^{1}$

\begin{tabular}{l|ccccccc}
\hline Country & $\begin{array}{c}\text { Government } \\
\text { Bonds }\end{array}$ & $\begin{array}{c}\text { Financial } \\
\text { Institutions }\end{array}$ & $\begin{array}{c}\text { Corporate } \\
\text { Bonds }\end{array}$ & $\begin{array}{c}\text { Domestic } \\
\text { Equity }\end{array}$ & $\begin{array}{c}\text { Mutual } \\
\text { Funds }\end{array}$ & $\begin{array}{c}\text { Foreign } \\
\text { Assets }\end{array}$ & Other \\
\hline Argentina & 60.9 & 5.1 & 1.8 & 13.4 & 8.1 & 8.9 & 1.8 \\
Bolivia & 70.0 & 6.8 & 13.5 & 6.3 & & 2.5 & 0.9 \\
Chile & 16.4 & 28.9 & 6.8 & 14.7 & 2.8 & 30.2 & 0.2 \\
Colombia & 47.3 & 10.4 & 14.4 & 11.3 & 2.0 & 10.4 & 4.3 \\
Costa Rica & 72.1 & 13.2 & 5.3 & 0.2 & 3.2 & 2.7 & 3.4 \\
Dominican R. & - & 96.8 & 3.2 & - & & - & \\
El Salvador & 81.0 & 12.7 & 6.3 & 0.0 & & - & \\
Hungary & 72.7 & 2.2 & - & 14.4 & & 7.9 & \\
México & 82.1 & 4.2 & 11.8 & 0.4 & & 1.5 & \\
Peru & 20.3 & 11.1 & 10.7 & 36.4 & 2.8 & 10.1 & 8.7 \\
Poland & $\mathbf{6 2 . 5}$ & $\mathbf{3 . 4}$ & $\mathbf{0 . 5}$ & $\mathbf{3 1 . 4}$ & & $\mathbf{1 . 7}$ & $\mathbf{0 . 5}$ \\
Uruguay & 59.5 & 36.8 & 2.7 & 0.1 & & & 0.9 \\
\hline Note: 1/ Some figur.
\end{tabular}

Note: 1/ Some figures are estimated due to differences in classification.

Sources: AIOS, HFSA.

26. The lack of diversification of pension fund portfolios reflects in part some investment restrictions, and in part the limited supply of financial instruments in the domestic capital market. The Polish capital market is dominated by the government bond and equity markets. The markets for privately issued fixed-income instruments such as mortgage-related securities, municipal bonds, and corporate bonds are negligible, amounting to less than 1 percent of GDP each. The limited supply is partly due to fiscal/macroeconomic factors, and partly to regulatory factors.

27. While the overall portfolio is still not very well diversified, the domestic equity portfolio seems to be relatively well diversified, including several medium and small caps. Pension funds have become important shareholders as a group, especially in smaller companies. The equity portfolio of pension funds is reasonably diversified, comprising investments in 167 listed companies. As shown in Table 9, the five largest companies account for half of the equity portfolio, but the other half is 
reasonably well diversified. The scope for more diversification is probably limited, as the shares of smaller companies tend to be much less liquid, and also because combined holdings of pension funds already amount to a significant share of the capital of these smaller companies, as shown in Table 9.

Table 9. Characteristics of the Equity Portfolio of Polish Pension Funds

\begin{tabular}{l|cc}
\hline $\begin{array}{l}\text { Companies Ranked by } \\
\text { Market Capitalization }\end{array}$ & $\begin{array}{c}\text { Share of largest companies in } \\
\text { total equity portfolio (\%) }\end{array}$ & $\begin{array}{c}\text { Share of combined pension fund } \\
\text { equity holdings in company equity } \\
(\%)\end{array}$ \\
\hline Top Five Companies & 52 & 10 \\
Ranked 6 to 20 & 16 & 8 \\
Ranked 21-50 & 18 & 22 \\
Ranked 50-100 & 7 & 27 \\
Remaining Companies & 7 & n.a. \\
Total & 100 & - \\
\hline
\end{tabular}

Source: KNUiFE.

28. The share of foreign assets is surprising low, especially considering Poland's membership in the EU. This outcome is probably due to low regulatory ceilings, the high returns in Poland, and regulations on commissions. The ceiling on foreign assets is only 5 percent, discouraging research on this asset class and its consideration in strategic asset allocation. Domestic returns have been high (see the section on returns below), also making foreign assets less attractive. The fact that commissions paid to foreign brokers or mutual funds cannot be netted from returns also makes these investments less attractive - since overall fees are capped, commissions charged by foreign brokers or mutual funds affect the PTE's profits and net worth.

\section{The portfolios of individual pension funds have become more similar in} recent years, at least regarding the shares of major asset classes. Since 2002 pension funds have held more similar portfolios, as indicated by the reduction in the coefficient of variation of the equity share in the total portfolio. As shown in Figure 5, the coefficient of variation of the equity share was about 25 percent in 1999-2002 but declined sharply to 5 percent in recent years. Pension funds are known to herd in other countries, but it is noteworthy that the rapid convergence of portfolios in Poland after 2002 was apparently due to an episode where one pension fund triggered the minimum return guarantee and the PTE had to honor the guarantee with its own assets. ${ }^{13}$

\footnotetext{
${ }^{13}$ Pension funds are known to herd, even in countries that adopt prudent man rules with few or no portfolio restrictions and that do not impose any return guarantees. For example, Blake, Lehmann and Timmermann (2002) find evidence of strong herding effect in the UK, resulting from the fear of asset managers to lose their mandates if their return performance is considered low compared to that of their peers. However, herding is probably intensified by the presence of a minimum return guarantee.
} 
Figure 5. Coefficient of Variation of the Equity Share in Pension Fund Portfolios, 2000-06

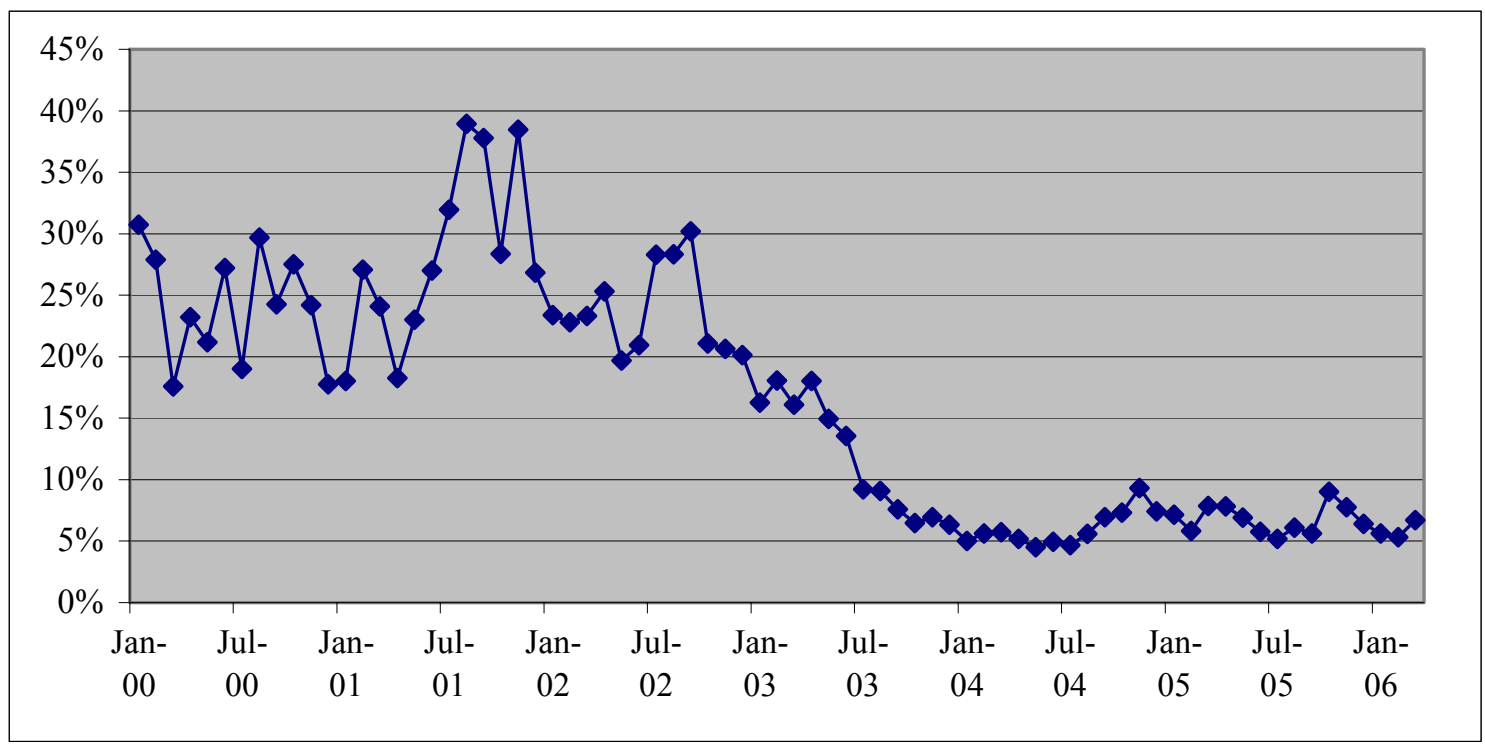

Source: KNUiFE.

30. While the overall share of equity is similar across pension funds, the equity portfolios look different, especially regarding the share of small and medium size companies. Figure 6 shows the differences in the composition of the equity portfolio across different pension funds, measured by the coefficient of variation of the share of each individual equity. ${ }^{14}$ Equities are sorted by their participation in the total equity portfolio. Equity portfolios tend to be similar for the 20 most important equities (accounting for 75 percent of total equity portfolio), but become more differentiated in the case of medium and small caps. A similar outcome holds in the case of the composition of fixed-income portfolio. As shown in Figure 7, fixed-income portfolios are similar for the 10 most important government bond instruments, but become more differentiated for the smaller issues.

\section{Rates of Return}

\section{Pension funds have generated high real rates of return, despite holding a} large share of government securities and other fixed-income instruments. As shown in Table 10, the average historic real rate of return has been 8.8 percent p.a. well above the growth rate of the real covered wage bill in the same period (the rate of return of the first pillar). The rates of return generated by Polish funds also compare very favorably with those of other reforming countries, as shown in Table 11. In 2005, the real rate of return was almost six percentage points above the average return in these countries. ${ }^{15}$

\footnotetext{
${ }^{14}$ A low coefficient of variation means that all pension funds hold a similar share of that equity.

15 The differences may be slightly wider, because most Latin American countries publish gross rates of return while in the case of Poland (and Hungary) rates of return are net of asset management fees.
} 
Figure 6. Coefficient of Variation of Equity Holdings, 2005

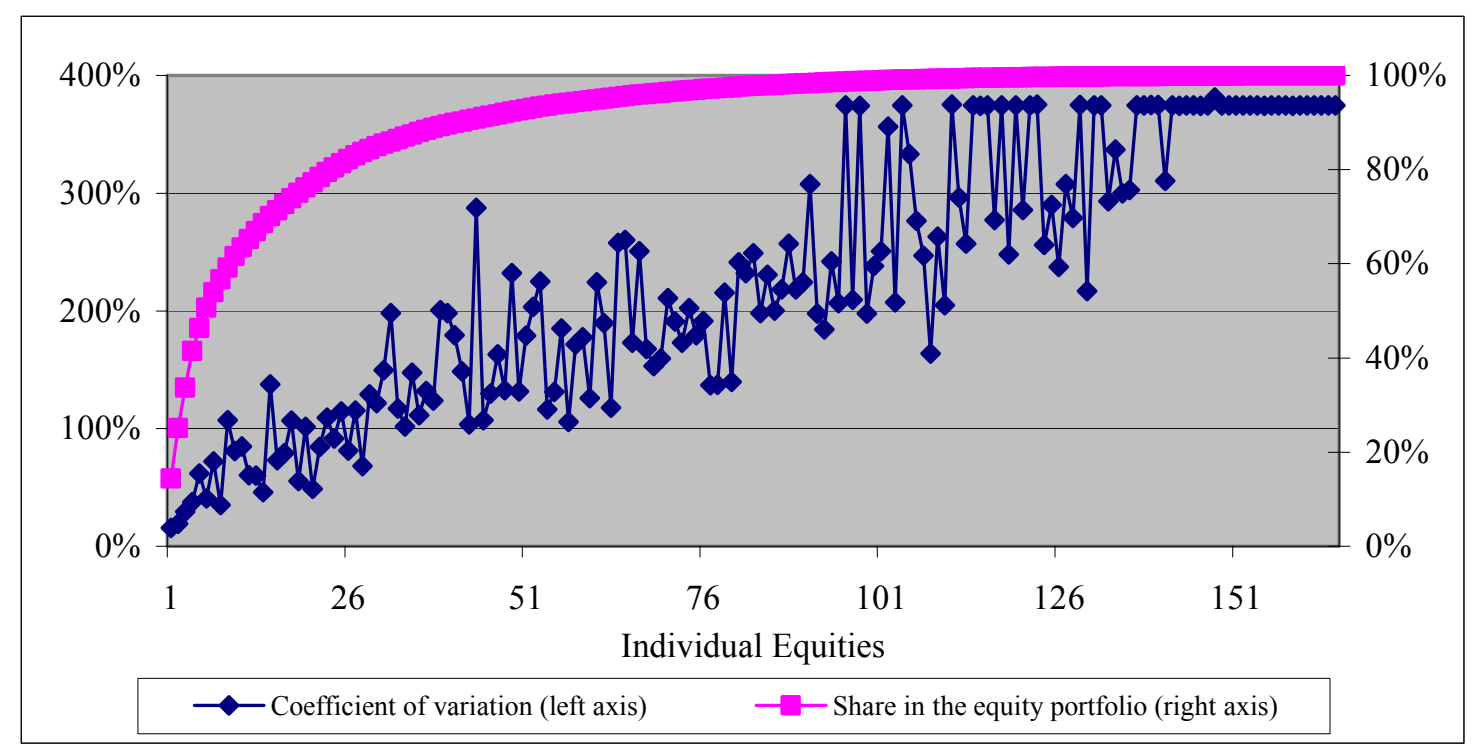

Note: Each number in the X-axis represents an individual equity.

Source: KNUiFE.

Figure 7. Coefficient of Variation of Fixed Income, 2005

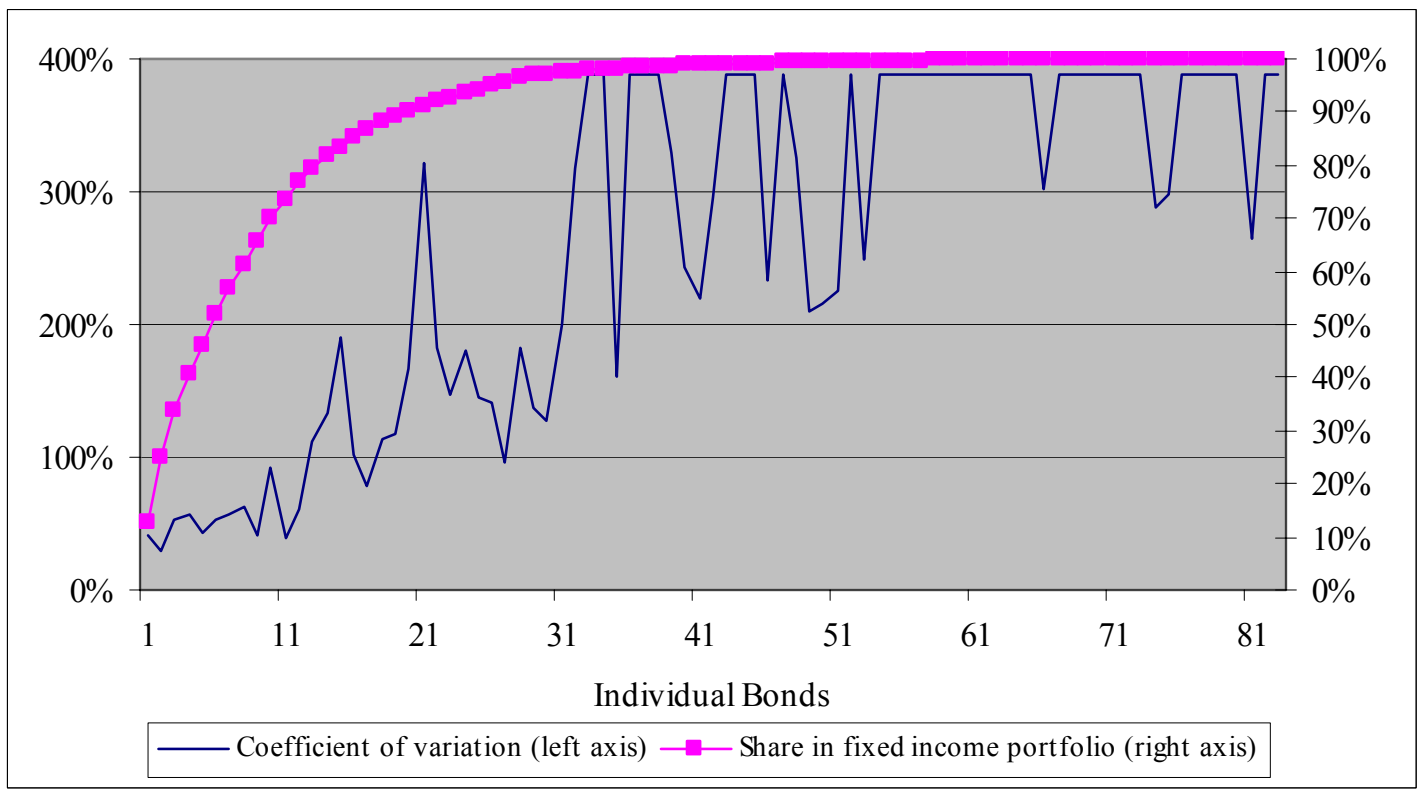

Note: Each number in the X-axis represents an individual fixed-income security. Source: KNUiFE.

32. Workers who have selected the new system have so far enjoyed higher returns on their contributions than workers who opted to stay at the old PAYG system, but the success of the young second pillar in maintaining this performance will depend on progress in diversifying portfolios and continue reducing commissions. The good return performance has been partly due to large capital gains on 
the fixed-income portfolio, resulting from the sharp decline in nominal and real interest rates in recent years (Figure 8). This source of high returns is practically exhausted, as interest rates are already low across the maturity spectrum. The good return performance has also been due to a buoyant domestic equity market, as indicated by real returns on the WIG20 (the index of the 20 largest caps) around 25-30 percent p.a. in the past three years. These yields can be not be sustained in the long-run either. Therefore, real rates of return in the future will depend more closely on progress in diversifying portfolios and extracting higher risk-adjusted returns on a wider range of assets, including foreign assets, and private domestic fixed-income instruments.

Table 10. Pension Fund Returns, Inflation Rate, GDP Growth and Indexation of NDC

\begin{tabular}{l|cccc}
\hline Year & $\begin{array}{c}\text { Real Annual } \\
\text { Rate or Return }\end{array}$ & Inflation Rate & Real GDP Growth & NDC indexation rate \\
\hline 2000 & $4.1 \%$ & $8.6 \%$ & $4.1 \%$ & $3.8 \%$ \\
2001 & $3.5 \%$ & $3.6 \%$ & $1.1 \%$ & $3.0 \%$ \\
2002 & $12.7 \%$ & $0.8 \%$ & $1.4 \%$ & $1.1 \%$ \\
2003 & $9.1 \%$ & $1.7 \%$ & $3.8 \%$ & $0.3 \%$ \\
2004 & $9.4 \%$ & $4.4 \%$ & $5.3 \%$ & $-0.7 \%$ \\
2005 & $14.2 \%$ & $0.7 \%$ & $3.2 \%$ & $4.8 \%$ \\
& & & & \\
Average since 1999 & $\mathbf{8 . 8 \%}$ & $\mathbf{3 . 3 \%}$ & $\mathbf{3 . 1 \%}$ & $\mathbf{2 . 0 \%}$ \\
\hline
\end{tabular}
Source: MoF, NBP, KNUiFE.

Table 11. Rates of Return of Second Pillar Pension Funds in Reforming Countries

\begin{tabular}{l|cccc}
\hline & \multicolumn{3}{|c}{ Annual Rate of Return (\%) } \\
\hline Country & $\begin{array}{c}\text { Average Nominal } \\
\text { Since Inception }\end{array}$ & $\begin{array}{c}\text { Average Real } \\
\text { Since Inception }\end{array}$ & Nominal 2005 & Real 2005 \\
\hline Argentina & 14.9 & 9.4 & 17.5 & 4.6 \\
Bolivia & 13.7 & 9.8 & 8.6 & 3.5 \\
Chile & 22.9 & 10.0 & 8.6 & 4.6 \\
Colombia & 20.7 & 8.3 & 24.8 & 19.0 \\
Costa Rica & 18.1 & 6.1 & 18.8 & 4.1 \\
Dominican R. & 20.6 & -2.3 & 17.1 & 9.0 \\
El Salvador & 12.4 & 9.3 & 5.8 & 1.5 \\
Hungary & 11.0 & 4.5 & 12.5 & 8.9 \\
Mexico & 16.3 & 7.7 & 11.5 & 8.0 \\
Peru & 13.2 & 8.8 & 20.2 & 18.4 \\
Poland & $\mathbf{1 2 . 3}$ & $\mathbf{8 . 8}$ & $\mathbf{1 5 . 0}$ & $\mathbf{1 4 . 2}$ \\
Uruguay & 23.0 & 12.0 & 9.7 & 4.6 \\
Average & $\mathbf{1 7 . 1}$ & $\mathbf{8 . 0}$ & $\mathbf{1 4 . 3}$ & $\mathbf{8 . 3}$ \\
\hline
\end{tabular}

Source: AIOS, staff estimates. 
Figure 8. Poland Yield Curves (end of year)

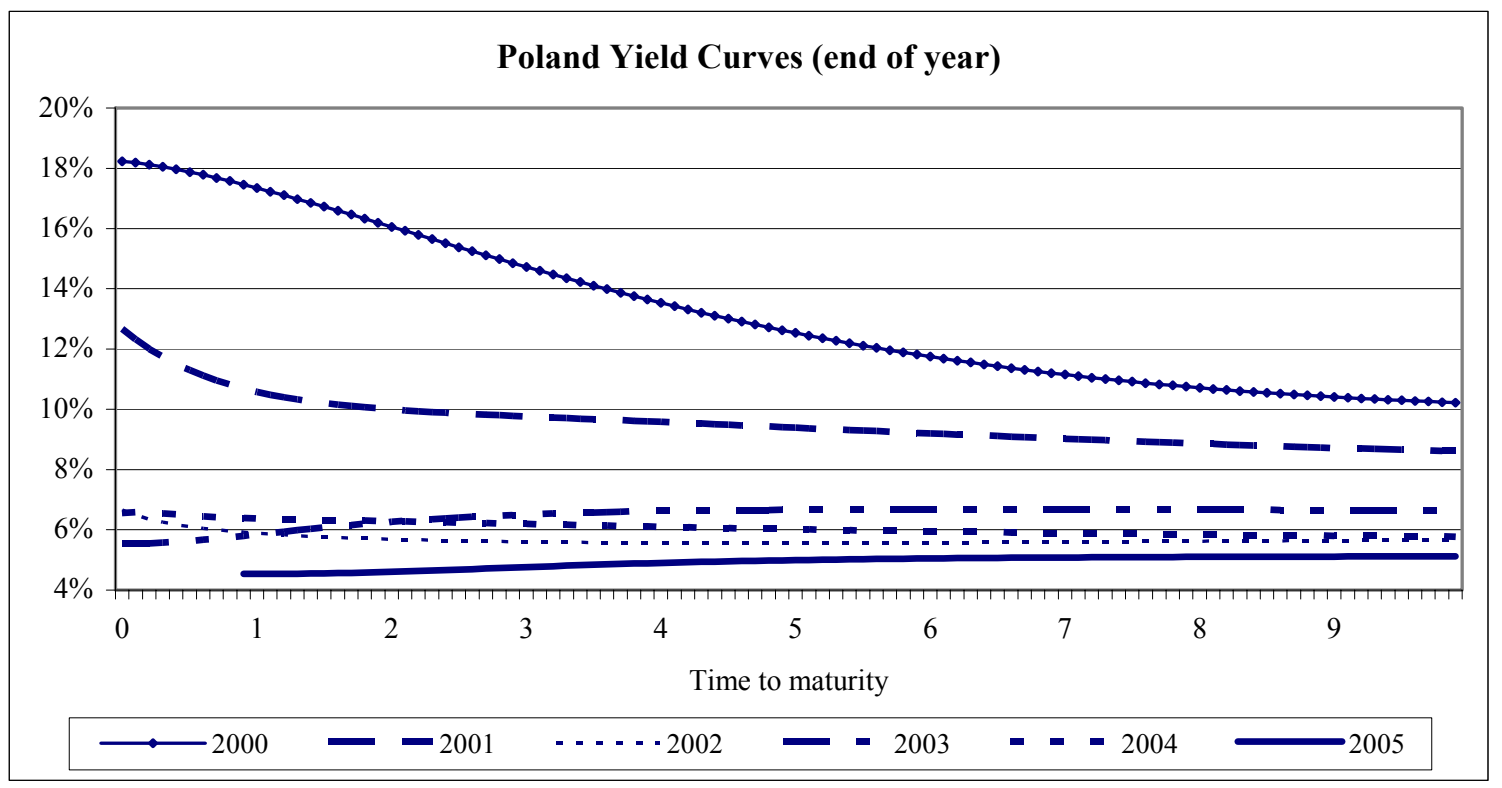

Source: NBP.

\section{Convergence of Rates of Return and the Minimum Return Guarantee}

33. Rates of return of individual pension funds have converged in recent years, reflecting the convergence of their portfolios, but remain moderately differentiated. As shown in Figure 9, the coefficient of variation of the annual rates of return of pension funds has declined significantly since 2001, reflecting the greater convergence of portfolios. However, rates of return have remained moderately differentiated in recent years, especially when compared with a country with a similar institutional framework such as Chile (Figure 10). This result probably reflects differences within major asset classes; as shown before, there is greater convergence in the holdings of major asset classes but some differentiation within these asset classes. The high rates of return of pension funds in recent periods have also reduced the probability of triggering the MRG and allowed some differentiation of portfolios and returns.

34. The recent relaxation of some of the parameters of the MRG may also be contributing to some differentiation. Parliament has approved a number of additional measures to reduce the effect of the MRG on pension fund portfolios, including extending the sample period from 24 to 36 months, moving from quarterly to semiannual evaluations and imposing a cap of 15 percent in the weight of large pension funds for the computation of the MRG. These measures have reduced somewhat the risk of triggering the MRG and may have contributed to some differentiation of portfolios and returns. 
Figure 9. Convergence of Returns of Polish Pension Funds

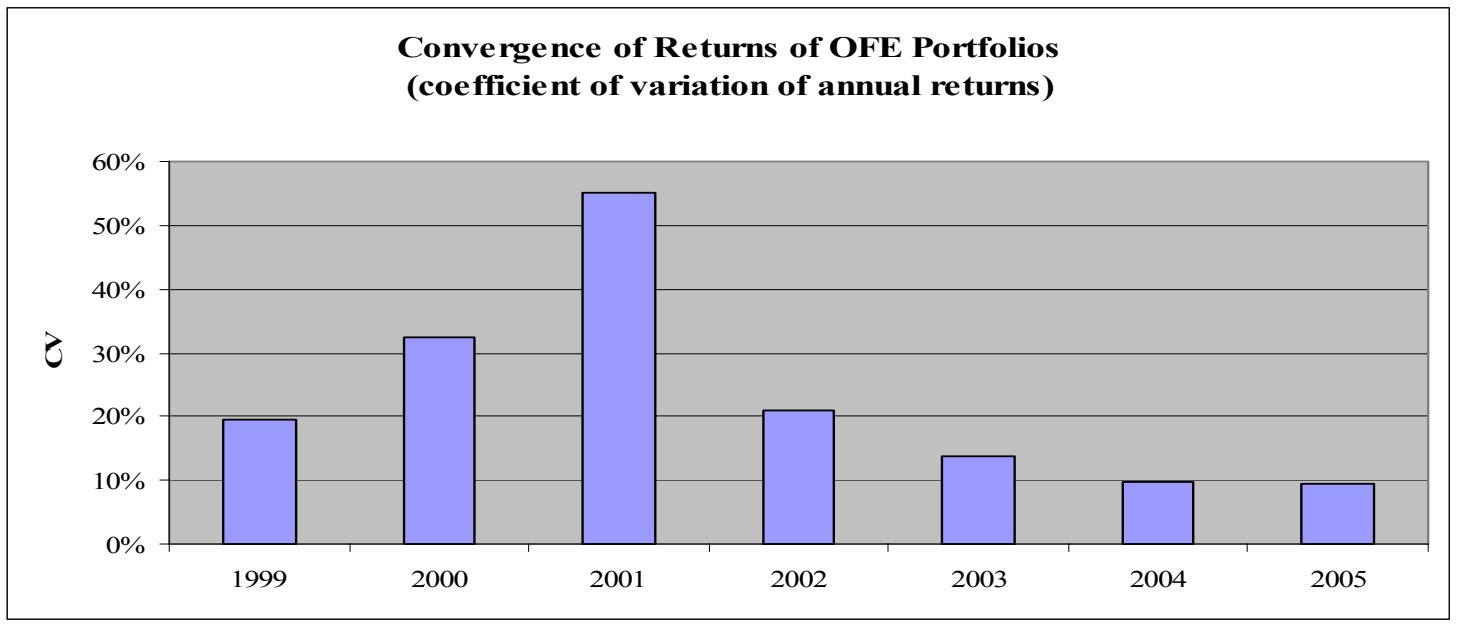

Source of raw data: KNUiFE.

Figure 10. Convergence of Returns of Chilean Pension Funds

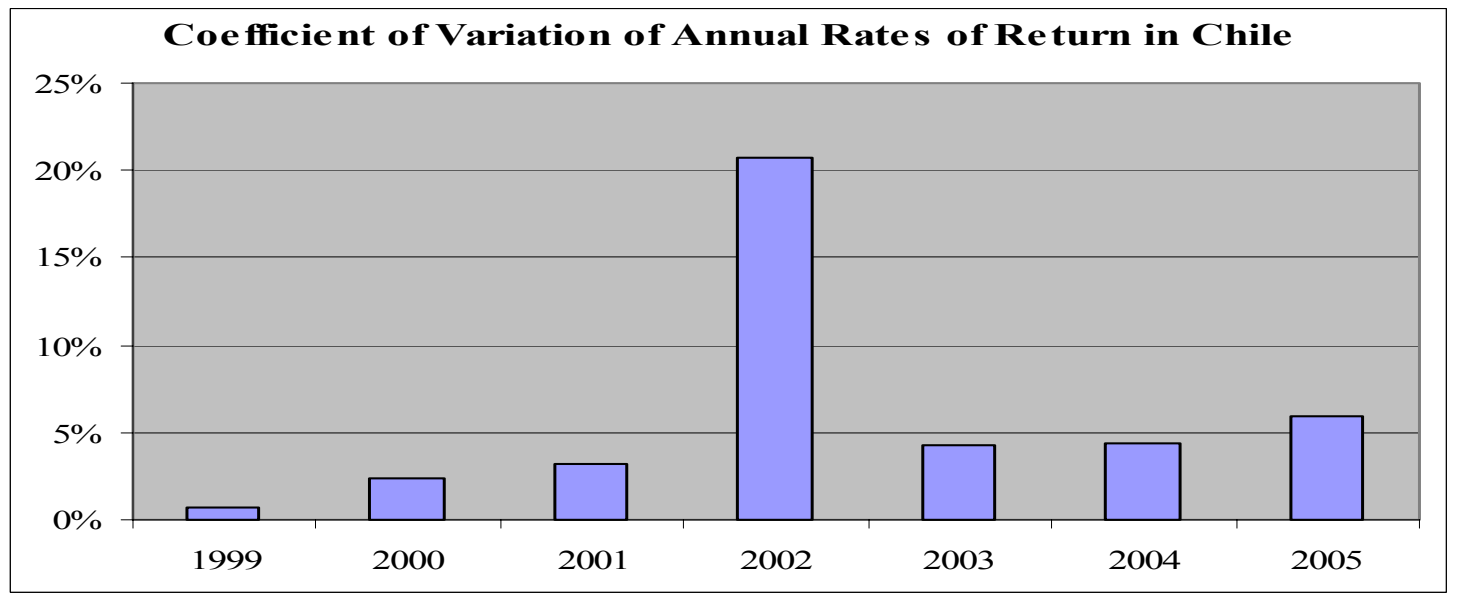

Source of raw data: SAFP.

Figure 11. Rates of Return of Polish Funds and the MRG

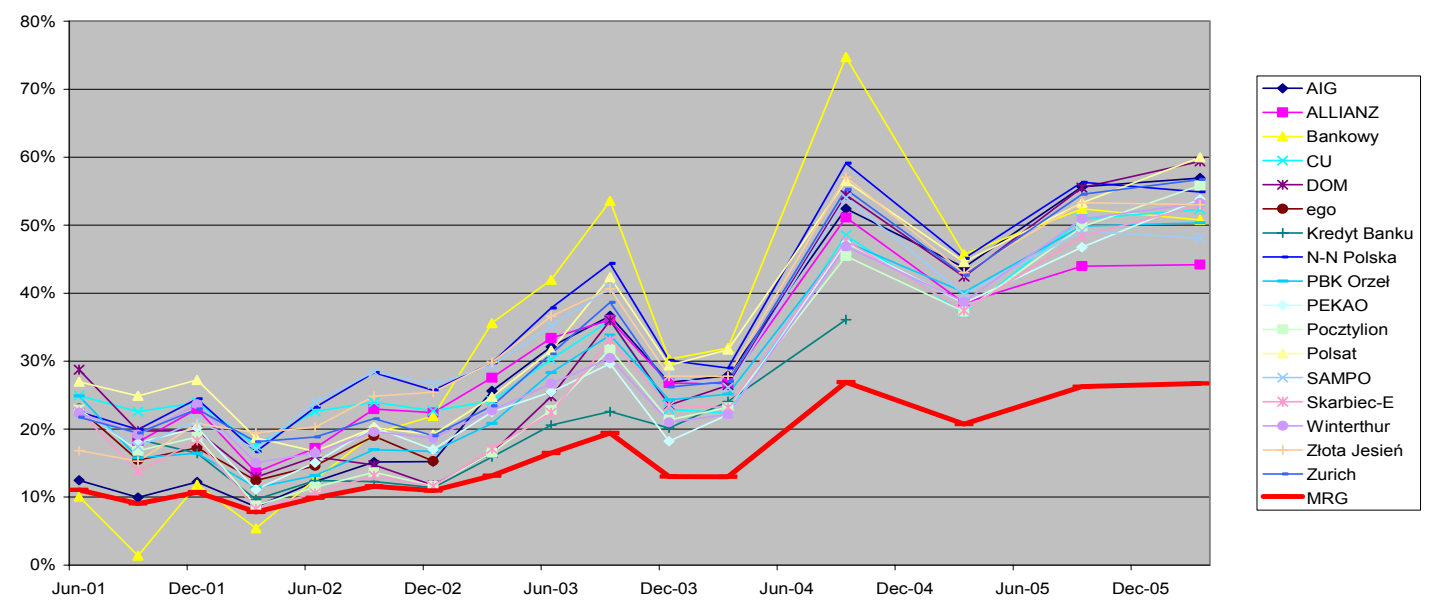

Source: KNUiFE. 


\section{Pension funds have been able to increase returns on a risk-adjusted basis in} the last three years. Sharpe and Modigliani ratios ${ }^{16}$ have increased in the past three years, as shown in Figures 12 and 13, suggesting reasonable investment policies, especially taking into consideration the limitations of the domestic capital market. The increase in Modigliani ratios suggests that pension funds have been more efficient than simply investing in a domestic equity index like WIG. It is also noteworthy that the apparent increase in efficiency coincides with the period in which portfolios converged. These are positive outcomes, but do not alter the basic conclusions reached above, namely, that the high returns have been partly due to extraordinary factors, and that the maintenance of a good return performance in the future will depend on efforts to diversify portfolios further.

Figure 12. Sharpe Ratios

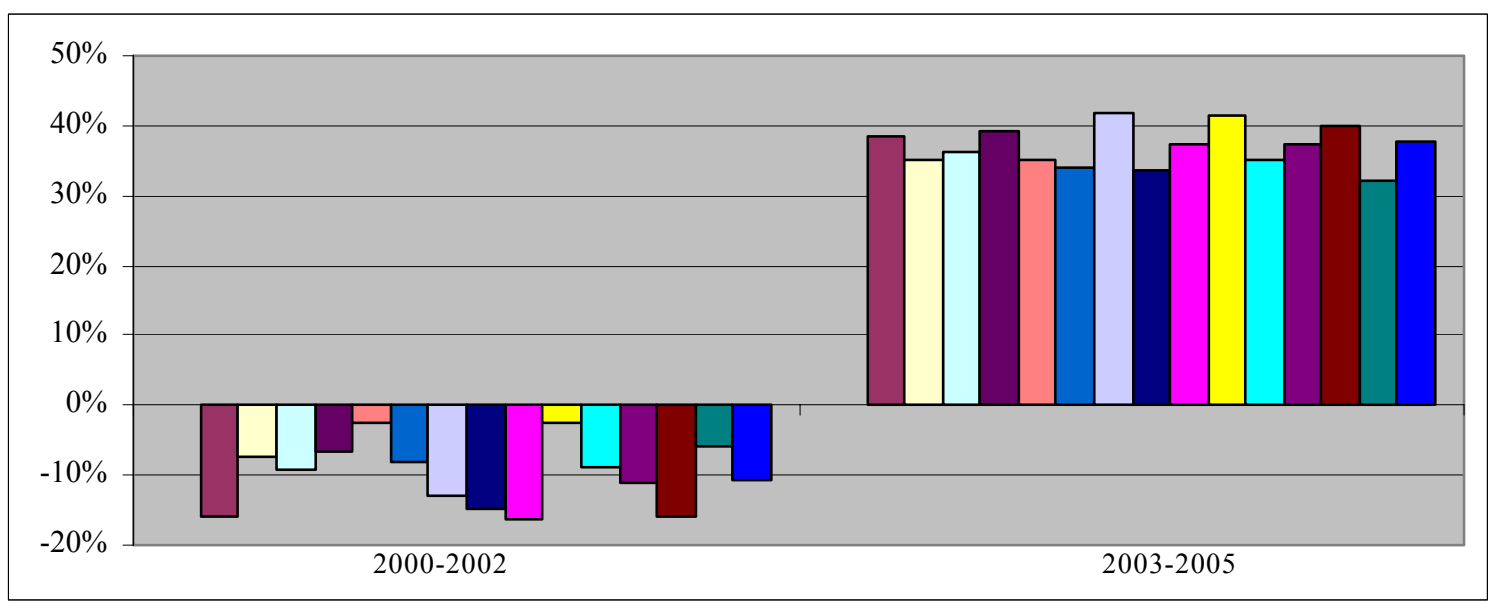

Note: Each bar represents an OFE. Source of raw data: KNUiFE and WSE.

\footnotetext{
${ }^{16}$ The Sharpe ratio divides the portfolio's excess return by the standard deviation of excess returns. A higher Sharpe ratio means that the fund delivers a higher return for a given unit of risk, reflecting a more efficient portfolio. The Modigliani ratio multiplies the Sharpe ratio by the standard deviation of the index excess returns. It has a more direct interpretation because it is measured as percentage points above the benchmark. The higher the ratio the more efficient is the portfolio.
} 
Figure 13. Modigliani Ratios (against WIG)

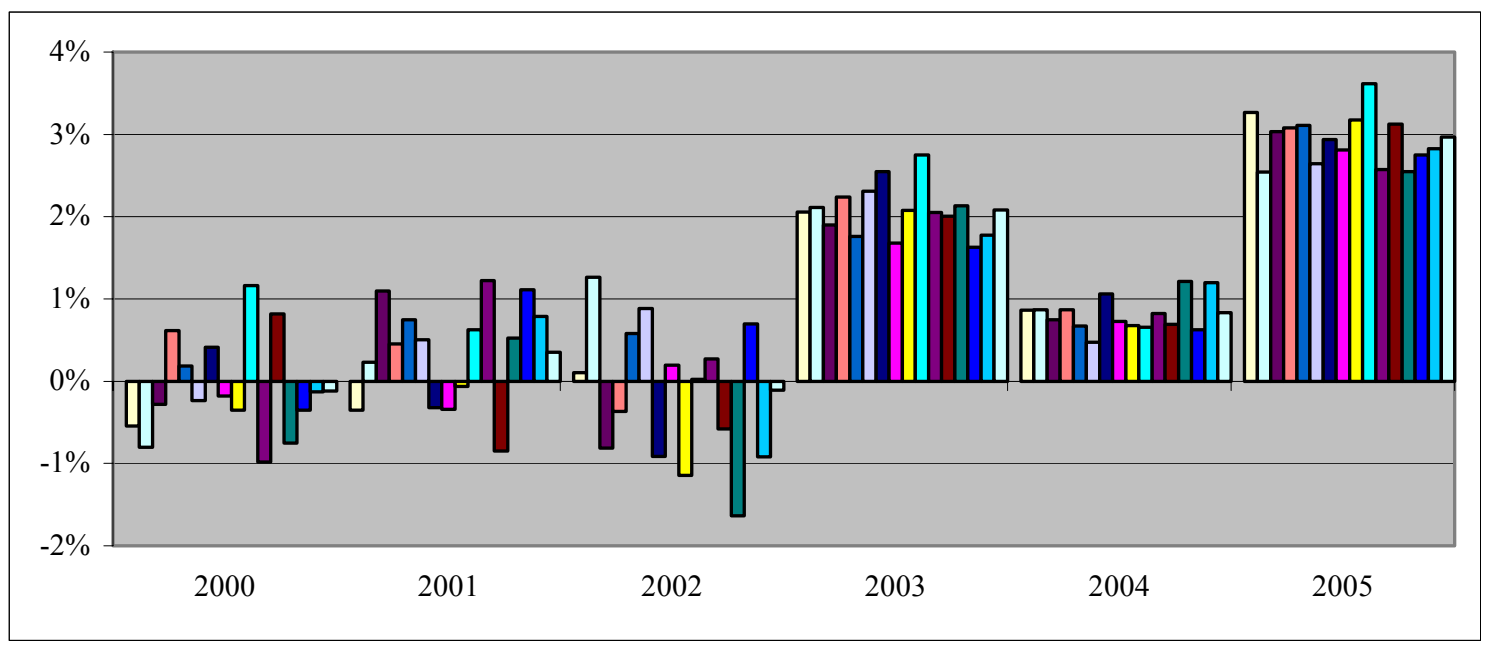

Source of raw data: KNUiFE and WSE.

Notes: Each bar represents an OFE. WIG is the equity index calculated by the WSE.

\section{Costs and Fees}

36. Polish pension funds seem to operate with low costs by comparison with other reforming countries. This outcome is probably due to centralized revenue collection arrangements and the capping of fees. As shown in Table 12, the Polish pension system operates with a cost per contributor of about USD 26, comparing favorably to the average cost of selected Latin American systems (USD 65). Marketing costs seem extremely low by comparison with other countries. ZUS charges 80 bps of the amount of contributions as a fee for collection services, suggesting that scale economies in revenue collection are strong and contribute to the low costs. At the same time, it is also possible that marketing costs are kept artificially low to some extent by some crosssubsidization by the insurance company within the financial group.

Table 12. Operational Costs of Pension Funds in Selected Countries, 2005

\begin{tabular}{cccc|c}
\hline & $\begin{array}{c}\text { Administration } \\
\text { Costs }\end{array}$ & $\begin{array}{c}\text { Marketing } \\
\text { Costs } \\
\text { (As a Percentage of Total Costs) }\end{array}$ & $\begin{array}{c}\text { Other } \\
\text { Costs }\end{array}$ & Total Costs \\
\hline Argentina & 55.3 & 42.9 & 1.8 & 65 \\
Chile & 71.4 & 25.9 & 2.7 & 75 \\
Colombia & 87.5 & 6.2 & 6.3 & 78 \\
Hungary & 65.5 & 4.7 & 29.8 & 29 \\
Mexico & 25.7 & 36.8 & 37.6 & 61 \\
Peru & 52.8 & 47.2 & & 80 \\
Uruguay & 47.5 & 25.5 & 27.1 & 32 \\
Average & 58.0 & 37.1 & 15.1 & 60 \\
\hline Poland & $\mathbf{8 3 . 4}$ & $\mathbf{2 . 8}$ & $\mathbf{1 3 . 8}$ & $\mathbf{2 6}$ \\
\hline
\end{tabular}

Source: AIOS, KNUiFE. 
37. Total fees amount to $\mathbf{1 6 0}$ basis points of assets, which is a reasonable result considering the short period of implementation and the small volume of assets. This outcome seems largely due to a highly regulated fee structure. PTEs charge fees on contributions and on assets and the legislation imposes ceilings on both types of fees. Fees on contributions have been capped at 7 percent for all new contracts issued after 2004. This cap will be progressively reduced to 3.5 percent in the year 2014 . All but one PTE charge the maximum contribution fee. Fees on assets are capped according to the volume of assets under management, as shown in Figure 14. As shown in Figure 15, including both management and contribution fee, the average PTE currently charges a total fee of about 160 basis points,. This is a reasonable result considering that the system has been operating for only seven years. There are large differences in the fees charged by PTEs, which largely reflect differences in size.

Figure 14. Ceilings on Asset Management Fees (basis points)

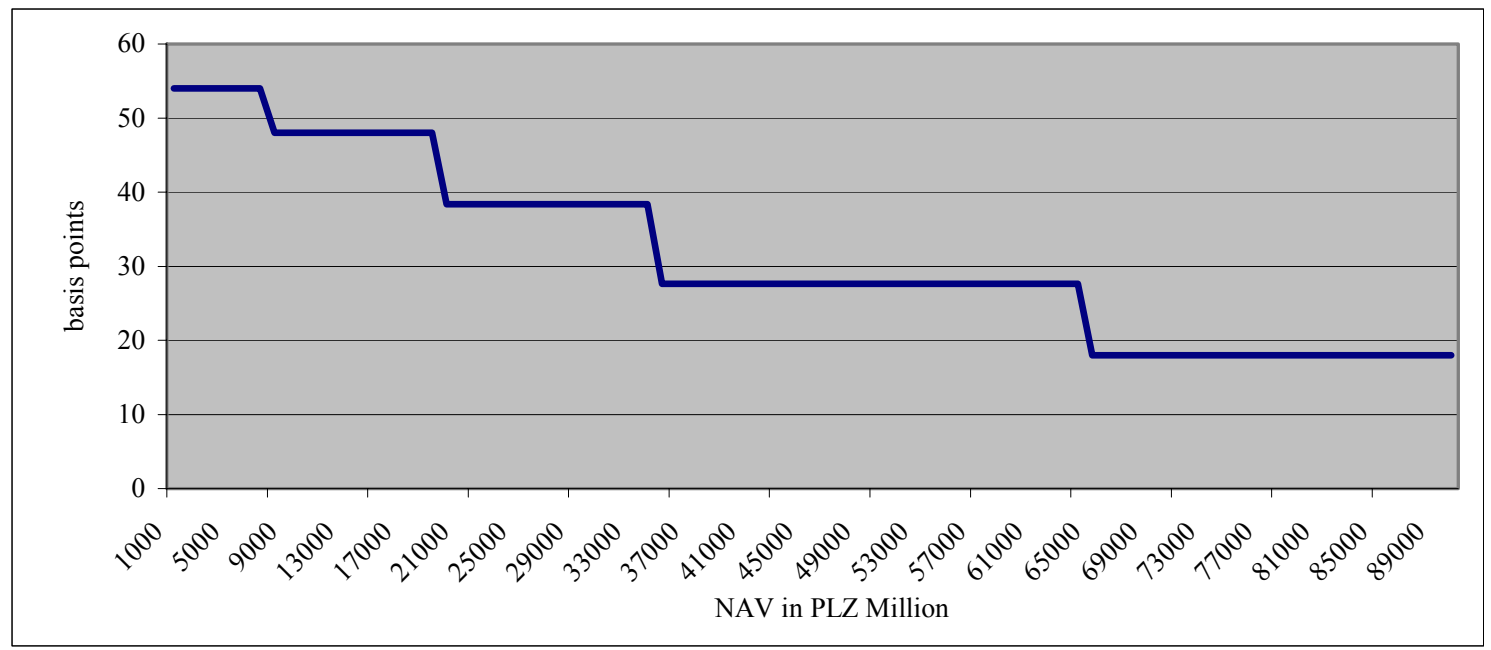

Note: Figures represent marginal rates.

Source: KNUiFE.

38. The average fee charged in the Polish second pillar compares favorably with the average fee charged in other reforming countries. The average fee in Poland is lower than the average fee charged in most countries with the same period of implementation. As shown in Figure 16, pension funds in other reforming countries charged on average 300 basis points in the seventh year of operation, a substantially higher level than the average fee charged in Poland. Also by way of comparison, it took fourteen years for the average fee in Chile to decline to 160 basis points. Poland also compares favorably with Hungary, which adopted a similar pension reform one year before Poland. The lower fees charged in Poland are largely explained by the achievement of important scale economies in revenue collection combined with the imposition of ceilings on fees. 
Figure 15. Ratio of Total Fees over Assets in 2005

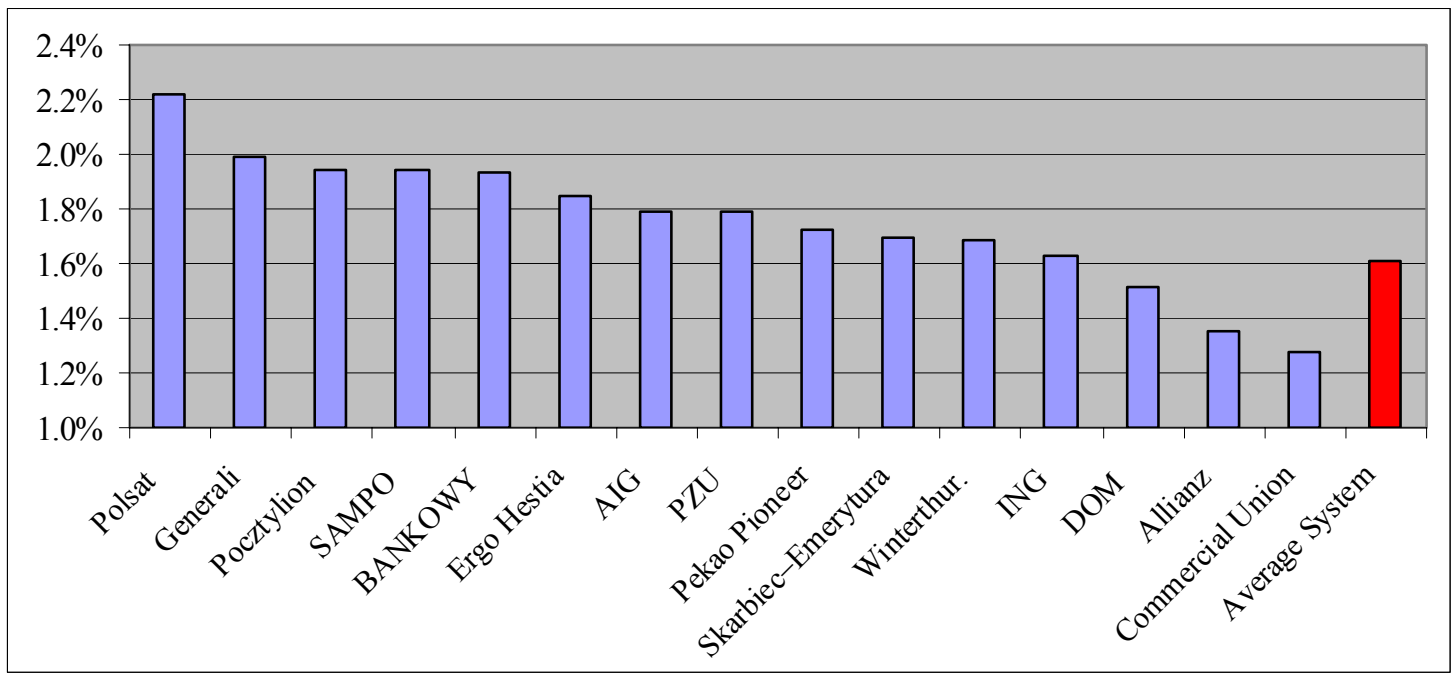

Source: KNUiFE.

Note: Total fees include both Contribution fee and Asset Management Fee. Assets are calculated as the average between 2004 and 2005 .

39. The average ratio of total fees over assets is projected to decline from $\mathbf{1 6 0}$ basis points at present to 50-60 basis points by 2020, due to the caps and asset growth. As shown in Table 13, total fees are projected to cross the threshold of 100 basis points in 2010, and to decline further to about 50-60 basis points in the following decade. ${ }^{17}$ This would make Poland one of the least expensive second pillars among reforming countries.

40. While the decline in fees would be a positive outcome, the implications of caps on the industry's structure would need to be assessed, especially regarding the financial feasibility of small pension funds. Under a conservative simulation scenario, in the next five years small pension funds will have to reduce their fees by 55 basis points in order to observe the ceilings (Table 13). It is not clear whether these funds will have sufficient scale to reduce costs, compete, and operate profitably within the ceilings. Note that some of the regulatory changes that are needed may imply an increase in costs, such as requirements for stronger internal risk management and controls.

41. The small funds have been kept alive in good part due to the system of lotteries that brings new members without the need to maintain a costly sales force. However, they will be increasingly vulnerable to marketing tactics by the larger funds. Lotteries have allowed small pension funds to survive but do not provide the basis for real competition with large pension funds. As fees are lowered further and profit margins are squeezed, small funds will become more vulnerable to even mild reductions in their membership base due to marketing tactics by the large funds. This may also

\footnotetext{
${ }^{17}$ At the same time, it is expected that the asset management fee may become the main source of revenues for the PTEs.
} 
constrain attempts by the regulators to enhance the quality of internal risk management and control procedures and quality of services if these imply larger costs.

Figure 16. Total Fees over Assets, Poland and Other Countries (\%)

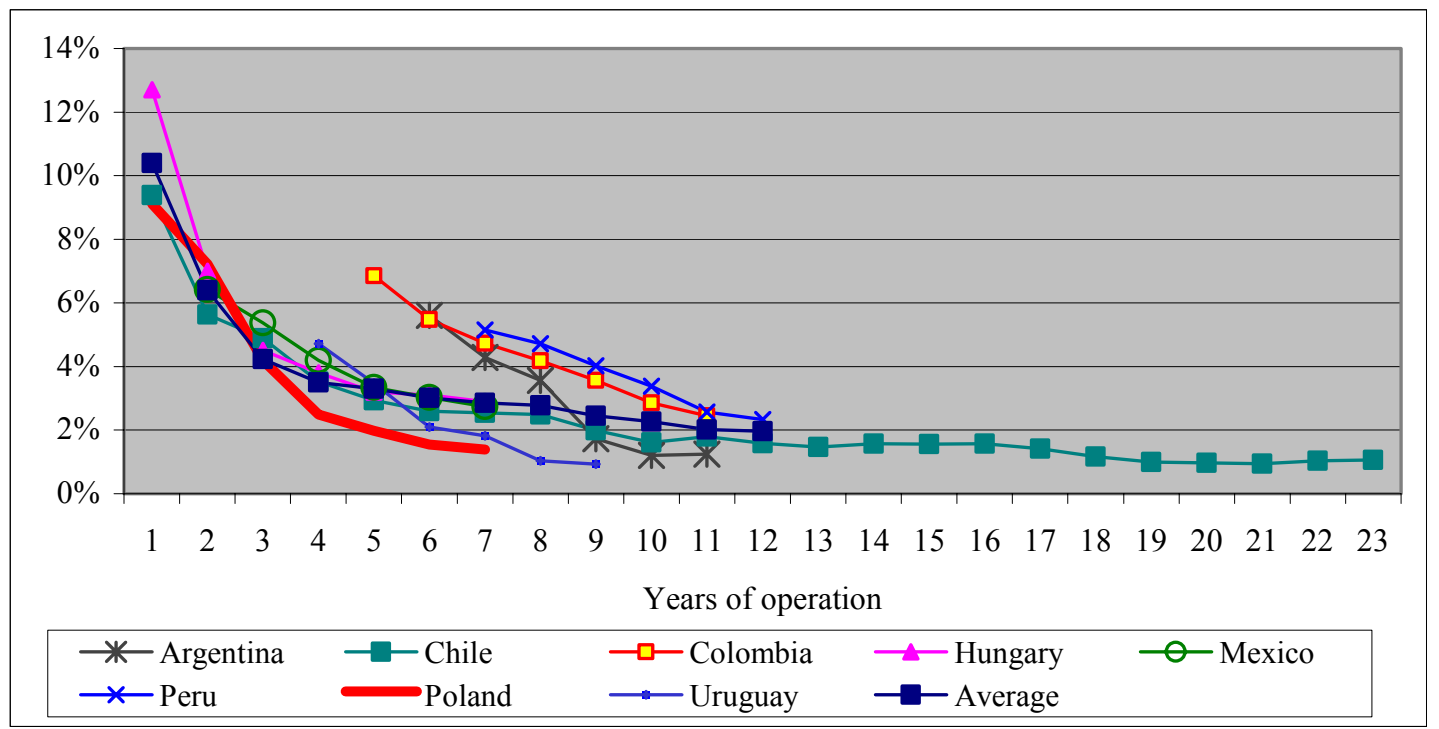

Source: Staff estimates based on country information.

Table 13. Projected Fees

\begin{tabular}{l|cccc}
\hline & \multirow{2}{*}{$\begin{array}{c}\text { Management Fee } \\
\text { (\% Total Fee) }\end{array}$} & \multicolumn{3}{c}{ Average Fee (\% Assets) } \\
\cline { 3 - 5 } & & Total System & Smallest Five OFEs & Largest Three OFEs \\
\hline 2005 & 30 & 1.51 & 1.61 & 1.36 \\
2010 & 52 & 1.02 & 1.05 & 0.93 \\
2020 & 83 & 0.61 & 0.69 & 0.43 \\
2025 & 86 & 0.54 & 0.62 & 0.35 \\
\hline
\end{tabular}

Source: Staff estimates.

\section{Profitability of PTEs}

42. During the first three years the industry ran losses, due to the start-up costs and the small initial level of assets and revenues. In the last three years, however, PTEs have generated high and stable returns, around 25 percent p.a., similar to the average ROE in other reforming countries. As shown in Table 14, the average ROE of PTEs has been higher than the average ROE of banks, which are subject to stricter capital requirements, manage a more complex business and bear much higher risks. ROEs of PTEs in Poland are comparable with those in other reforming countries. As shown in Table 15, pension fund administrators in other countries have also been able to recover its initial costs within relatively few years and to generate high ROEs in recent years. This result is not surprising, as the pension fund management industry is primarily an asset 
management business with relatively low capital requirements. However, the concentrated structure and the persistence of high ROEs has become a policy issue in most reforming countries, including Chile.

Table 14. Annual Nominal Return on Equity of Polish PTEs and Banks

\begin{tabular}{lcc}
\hline & PTEs & Banks \\
\hline 2000 & - & $15 \%$ \\
2001 & $-28 \%$ & $12 \%$ \\
2002 & $1 \%$ & $6 \%$ \\
2003 & $28 \%$ & $6 \%$ \\
2004 & $22 \%$ & $17 \%$ \\
2005 & $24 \%$ & $21 \%$ \\
\hline
\end{tabular}

Source. KNUiFE, GIBS.

Table 15. ROEs of Pension Fund Managers in Selected Countries (\% p.a.)

\begin{tabular}{l|cc}
\hline Country & 2004 & 2005 \\
\hline Argentina & -10.0 & 3.4 \\
Bolivia & 38.8 & 50.7 \\
Chile & 21.0 & 19.5 \\
Colombia & 27.6 & 29.2 \\
Costa Rica & -18.9 & 12.8 \\
El Salvador & 30.8 & 38.8 \\
Hungary & 16.3 & - \\
Mexico & 25.2 & 15.5 \\
Peru & 52.5 & 41.1 \\
Poland & $\mathbf{2 2 . 1}$ & $\mathbf{2 7 . 8}$ \\
Dominican Republic & -20.7 & -5.8 \\
Uruguay & 39.0 & 39.6 \\
\hline Average & $\mathbf{1 8 . 6}$ & $\mathbf{2 4 . 4}$ \\
\hline
\end{tabular}

Sources: AIOS, KNUiFE, HFSA.

43. There are important differences in profitability across PTEs of different sizes. The larger PTEs have been able to stabilize their profits but the smaller PTEs seem to be still struggling to consolidate their financial situation. As shown in Figure 17, while the ROEs of large PTEs such as Commercial Union, ING and PZU have been high and stable in recent years, the profitability of small and medium PTEs has been volatile, despite some measures adopted by regulators to keep these PTEs afloat, such as favorable rules for the allocation of new entrants. As mentioned before, it is not clear whether the smaller PTEs will be able to operate profitably in a scenario of declining fees. It is possible that the projected decline in fees will be associated with further consolidation of the pension fund management industry. 
Figure 17. Return on Equity of PTEs (\%), 2002-2005

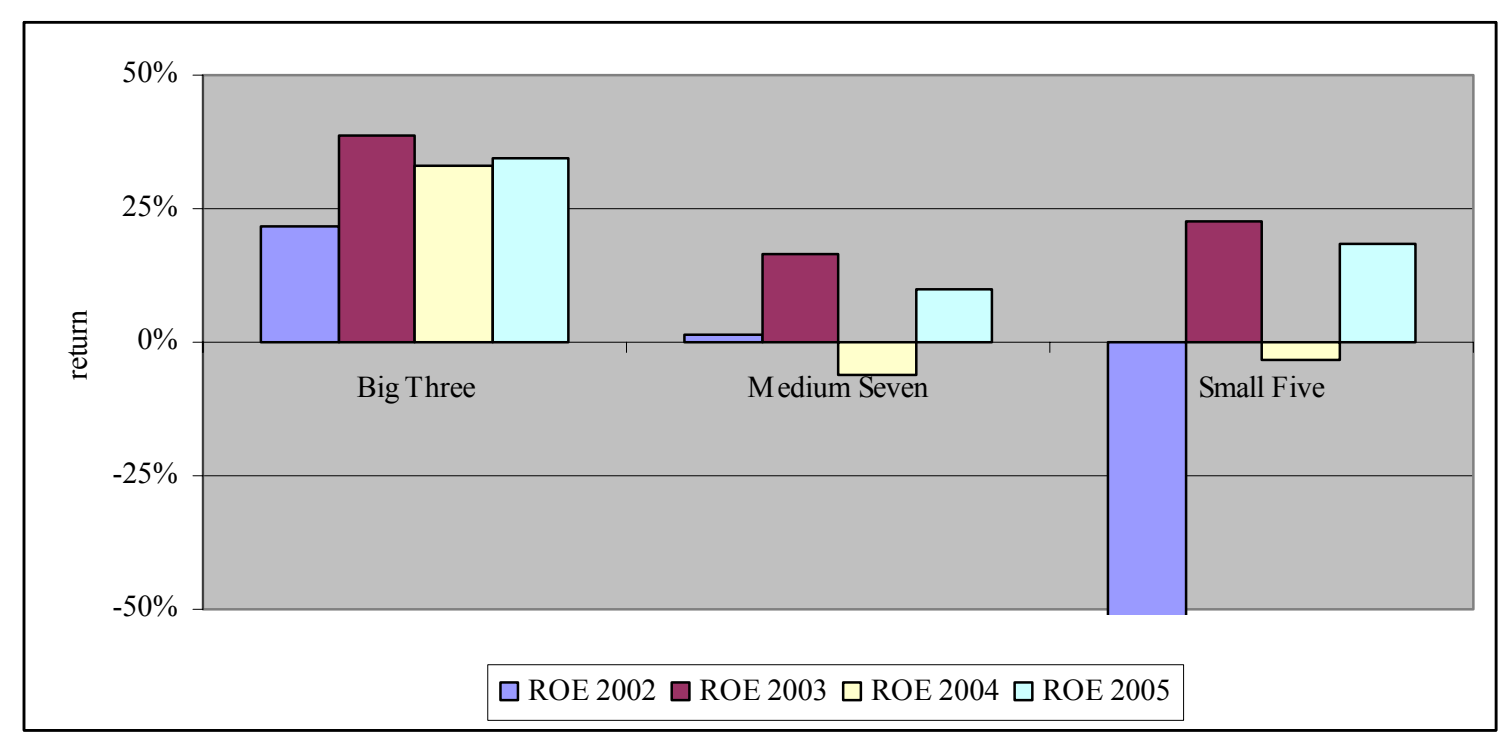

Source: KNUiFE.

Note: ROEs are calculated as simple averages. The ROE for the smallest five in 2002 was $-102 \%$.

\section{MAIN REgUlatory AND SUPERVISORY ISSUES}

\section{A. An Overview of the Regulatory Framework}

44. The regulatory framework for the pension fund sector is defined by the Law on the Organization and Operation of Pension Funds, first enacted in 1997 but submitted to various amendments since then. Secondary regulation is defined by nine Government and Ministerial Decrees in areas such as investment regulation, valuation of assets, and guarantee fund. The agency in charge of supervising the pension and insurance industries - KNUiFE - does not have the power to issue binding secondary regulation. Other laws regulating capital market operations also affect operations of pension fund managers.

45. The regulatory framework is generally sound, but may need some revisions in critical areas, such as areas related to corporate governance, the investment regime, and the design of the MRG. The regulatory gaps have not caused major disruptions in the system as instruments purchased by pension funds are still relatively simple, but as portfolios become more diversified, it will be important to make sure that that the quality of the regulation moves along.

\section{Licensing Criteria}

46. Pension fund managers (PTEs) require a license issued by KNUiFE to manage an open pension fund (OFE). The minimum required capital to create a PTE is EUR 5 million. Licensing criteria also include full identification of the shareholders of the company and reasonable fit and proper tests including broad qualifications for 
shareholders and senior managers of the PTE. KNUiFE has to provide an answer within 3 months after the application was filled and has the authority to reject a license. Any changes in ownership due to mergers and acquisitions, changes in the management of the PTE and changes in bylaws have to be approved by KNUiFE; although the Law does not specify any timetable for responses. There have not been any applications for new licenses in the past few years.

\section{Corporate Governance}

47. As in the case of Chile and other reforming countries PTEs in Poland are legally structured as joint stock companies with the sole purpose of managing an open pension fund. However, unlike Chile and other Latin American countries, PTEs are managed by a two-board system. The general assembly appoints the members of the supervisory board, while the management board is generally appointed by the supervisory board. This two board system is relatively common in Continental Europe, although the roles of the two boards were adapted to the situation of pension funds, in particular the need to protect the interests of contributors, not only the shareholders. The management board makes most of the fundamental decisions, including the investment policy. The supervisory board approves the budget, the financial plan, and the audit reports. Some PTEs have appointed committees, such as audit, remuneration, and investment committees, but regulations do not impose them as requirements.

48. There are requirements of independence and technical expertise for the members of the management and supervisory board. The management board must have at least 3 members and at least one of the members must have a degree in Law or Economics. The supervisory board needs to have at least three members. Members of the first supervisory board are appointed for a two-year period and for the successive boards they cannot be appointed for a period longer than five years. At least half of the members of the supervisory board has to be independent, i.e., they should not be appointed by the shareholders nor represent their interests, but the interests of contributors. Not less than half of the members of the supervisory board must have a degree in Law or Economics. KNUiFE needs to approve all the members of the supervisory and management boards.

49. While the Pension Law and the Decrees contain a number of positive features, they do not provide sufficient guidance on key elements of the corporate governance architecture, especially regarding internal risk management and internal controls. The regulatory framework does not specify in detail the duties and obligations of board members, nor minimum standards for internal risk management and internal controls. Some PTEs have already implemented reasonable risk management systems, which include inter alia the appointment of a chief risk officer in charge of controlling financial and operational risks, but this is being done on a voluntary basis as a result of an internal policy of the financial group. Currently there are important differences in the quality of internal risk management systems of PTEs in Poland. 


\section{The Guarantee Fund}

50. PTEs have to maintain a Guarantee Fund to offset losses in cases where returns fall below the Minimum Return Guarantee. The system seems less onerous than the one in Chile and other Latin American countries. The Guarantee Fund is divided in two funds: the base fund and the additional fund. The base fund is managed by the National Depository of Securities. PTEs have to deposit in the base fund a certain percentage of the net asset value (NAV), which is equal to 0.1 percent. PTEs also have to deposit between 0.3 and 0.4 percent of the NAV in the additional fund. The additional fund is invested in the same portfolio of the OFEs and is managed by the same PTE. The additional fund is equivalent to the minimum reserve requirement or encaje, found in Chile and other Latin American countries, but these countries typically charge between one and two percent of the NAV, which is considerably higher than the charge in Poland.

51. If the MRG is triggered, these reserves are used in a sequence that minimizes moral hazard, but that may reinforce herding behavior. If the rate of return of a pension fund falls below the MRG, the difference should be covered by the resources of the Additional Fund. If the Additional Fund is depleted, the deficit should be covered by the capital of the PTE. The Base Fund is used if the deficit persists. In the event of a depletion of the Base Fund, the deficit should be covered by the Additional Funds of other pension funds. As a last resource, the deficit would be covered by the state budget. The sequence is reasonable, as it involves the specific reserves and capital of the pension and the asset manager, before the use of collective funds. However, it still reinforces the incentive for pension funds to herding that has been observed in Chile and other reforming countries. ${ }^{18}$

\section{Accounting, Valuation, and Auditing Standards}

52. The regulatory framework allows different methodologies for valuing the same instrument, opening room for different valuations of the same instrument at the same time by different pension funds. All securities are deposited at the National Depository of Securities and under the custody of a custodian bank that is independent from the PTE. The PTEs report asset values to KNUiFE on a daily basis. The Law provides the general methodology for asset valuation. This has proved sufficient for the moment, as pension funds are either invested in traded stocks or in fixed-income instruments which are easier to value. ${ }^{19}$ However, as pension funds diversify further their portfolios, differences in valuation may have a more significant impact on the value of the assets, possibly distorting valuation and comparisons across funds. ${ }^{20}$

53. The scope of external audits is relatively narrow and do not include an assessment of the quality of internal risk management and control systems. The

\footnotetext{
${ }^{18}$ There are incentives to herd at the time that all pension fund managers end up being liable for the poor return of any pension fund.

${ }^{19} \mathrm{KNUiFE}$ argues that different methodologies can be statistically equivalent.

${ }^{20}$ The methodology for the valuation of less liquid and more complex instruments needs to be approved by KNUiFE. This approach may not be appropriate when portfolios diversify and KNUiFE needs to handle a larger number of cases involving more complex instruments such as derivatives.
} 
annual audits involve a review of the financial statements of PTEs and do not include a review of internal systems and controls, providing little value to supervisors. In general, there is little interaction between auditors and supervisory authorities, and the external audit function seems to be under-utilized. ${ }^{21}$

\section{Investment Regulation}

54. The investment regime is relatively simple, being mostly based on ceilings by major asset classes. There are also some specific limits by issuer. Investment limits are set by a Resolution of the Council of Ministers, which gives certain degree of flexibility to the system to introduce new instrument or conduct fine tuning of investment regulation. This situation compares favorably with other countries where all limits are set in the Law (i.e. Chile), and consequently any change in parameters has to be approved by Congress.

55. Pension funds are authorized to trade in the over-the-counter (OTC) market, which in Poland is not very transparent, opening room for price manipulation. One of the most noteworthy differences between Poland and other countries with open pension systems is the permission for pension funds to trade both equities and fixedincome instruments in the OTC market, in a context where the market is not sufficiently transparent. $^{22}$ This situation is aggravated by the absence of detailed valuation rules. Most reforming countries whose market infrastructure is deficient require pension funds to conduct their transactions in formal exchanges or electronic platforms. The most advanced markets have standardized procedures for asset valuation, ensuring one price per instrument at each moment of time.

56. These risks are aggravated by deficiencies in risk management and internal controls in some PTEs and broker-dealers. As mentioned before, KNUiFE does not impose minimum standards for internal risk management and controls, which results in large difference across PTEs. Although some broker-dealers are required to implement some internal control mechanisms, the Warsaw Stock Exchange does not act as a Self Regulatory Organization (SRO), leaving broker dealers with a relatively light supervisory burden. Although this is not a major issue of concern for highly liquid instruments, it may create incentives for market agents to simulate transactions at artificial prices in the OTC market that can reflect hidden commissions to asset managers.

57. The current regulatory framework opens room for using investment funds as a mechanism to circumvent investment restrictions. The investment regime for pension funds imposes a 25 percent limit on holdings of investment fund shares or quotas, but does not impose restrictions on the underlying assets of closed-end investment funds, allowing pension funds to circumvent their own limits. ${ }^{23}$ For example,

\footnotetext{
${ }^{21}$ The pension fund industry has not yet fully adopted international financial reporting standards, but it is difficult to determine the extent to which this would change financial results.

${ }^{22}$ Note that transactions in the OTC market are only published in newspapers, and are not captured in the price databases used for valuation

${ }^{23}$ Investment funds are classified in closed-end, open-end and specialized.
} 
the 5 percent limit on foreign assets could be in principle circumvented through holdings of shares of investments funds specialized in foreign investments.

58. The 35 percent limit on investment fund quotas seems high for a pension system that has 15 PTEs and other market actors. By way of comparison, Chilean regulators also impose a 35 percent limit on mutual fund quotas, but this limit was a consequence of the consolidation of the pension industry (only six pension fund managers) and the lack of other institutional investors interested in investing in shares of investment funds. Poland has a larger number of pension funds and a larger number of domestic and foreign institutional investors and should not need to raise the limit to such a high level. The higher the participation of pension funds in investment funds, the higher the probability of using the latter as an instrument to circumvent investment restrictions.

59. The restrictions on non sovereign fixed-income instruments seem excessive compared to those imposed on the rest of the portfolio, and do not address effectively the risks of these instruments. As shown in Table 16, investment limits on non sovereign fixed-income instruments are not based on ratings but on criteria that do not reflect the underlying risks accurately. Other reforming countries (i.e. Chile, Colombia, and Mexico) have adopted ratings as the main mechanism to determine eligibility for investment in fixed-income instruments. The investment regime in Poland gives a generous room for pension funds to invest in secured bonds (40 percent), which add very little value in terms of spreads and credit risk given the very high standards that are required, and imposes a relatively low limit of 10 percent for investments in plain vanilla corporate bonds, which are instruments that can provide yield to portfolios and whose credit risks can be reasonably diversified. ${ }^{24}$ In fact, corporate bonds are less risky than equity, and there is no compelling reason to impose a lower limit on corporate bonds than on equity, at least for rated instruments. ${ }^{25}$ The low limit on unsecured fixed-income instruments may be one of the factors explaining the lack of development of the corporate bond market in Poland.

Table 16. Ceilings on Investment in Fixed-income Instruments (\% of total assets)

\begin{tabular}{lccc}
\hline & \multicolumn{2}{c}{ Security Type } & Investment Limit \\
\hline Municipal Bonds & & Traded Publicly & $40 \%$ \\
& & Non Traded Publicly & $20 \%$ \\
& \multirow{3}{*}{ Secured } & Traded Publicly & $40 \%$ \\
& & Non Traded Publicly & $10 \%$ \\
Mortgage Bonds & Unsecured & & $10 \%$ \\
Revenue Bonds & & $40 \%$ \\
Source: KNUiFE, NBP. & & $20 \%$
\end{tabular}

60. Restrictions on foreign assets seem excessive, preventing pension funds to enjoy the benefits of international diversification. Holdings of foreign assets are

\footnotetext{
${ }^{24}$ In March 2005, the corporate bond limit (unsecured) was increased from 5 to 10 percent of assets.

${ }^{25}$ Pension funds are allowed to invest up to 40 percent of the assets in equity. This limit has been a non binding constraint for pension fund portfolios.
} 
restricted to 5 percent of the portfolio. Pension funds have invested less than 2 percent of their assets in these instruments, possibly leading to the conclusion that the ceiling is not binding and does not need to be increased. In fact, the ceiling may be so low as to discourage any serious consideration of foreign assets in the strategic asset allocation. Some investment managers and risk officers of PTEs have indicated that they are not willing to invest resources in research and take a strategic decision to invest abroad when the amounts allowed by regulation are not significant.

\section{The Minimum Return Guarantee (MRG)}

61. The MRG in Poland is similar to those adopted in most reforming countries, but the parameters have provided more flexibility. Most countries that have introduced second pillar have adopted an MRG as a mechanism to avoid major discrepancies among returns of pension funds. The MRG has usually been expressed relative to the average return of the pension industry, and has been accompanied by the imposition of minimum reserves by the management company. This construction may have intensified the herding behavior of pension funds due to the risk for the owners of the AFP of losing their capital if the return guarantee is triggered.

62. The design of an MRG usually involves five major components: (i) the type of benchmark (relative, absolute, or a combination); (ii) the width of the bands; (iii) the assessment period; (iv) the frequency of evaluation; (v) the frequency and degree of disclosure of portfolios. As shown in Table 17, Poland has generally adopted reasonable parameters, including relatively wide bands, long assessment periods, bi-annual evaluations, and bi-annual detailed disclosure of the portfolios.

63. The approach adopted in Poland provides some flexibility for asset managers to operate. The wider bands reduce the risk of triggering the guarantee. The longer assessment period provides some flexibility to deviate from the benchmark and increases the incentives to focus on medium-term returns (although it also increases the persistence of returns, making it more difficult to reverse a trend); the lower frequency of evaluation provides some flexibility to deviate from the benchmark and correct deviations. The less strict disclosure requirements reduce the free rider problem and increases incentives to invest in research and deviate from the benchmark. In addition, Poland also applies a cap on the weights of large pension funds in the calculation of the benchmark that provide some margin for individual deviations from the benchmark. 
Table 17. Design of the Minimum Return Guarantee in Poland and Other Countries

\begin{tabular}{|c|c|c|c|c|}
\hline Country & Benchmark and Bands & $\begin{array}{l}\text { Assessment } \\
\text { Period }\end{array}$ & $\begin{array}{c}\text { Frequency of } \\
\text { Evaluation }\end{array}$ & Disclosure of Portfolios \\
\hline Argentina & Min $(70 \%$ of ARS, ARS - $2 \%)$ & 12 months & Monthly & \\
\hline Colombia & $\begin{array}{ll}\text { A } & 70 \% \text { of ARS } \\
\text { B } & 70 \% \text { of RSP } \\
& 70 \% \text { of Return of BVC index } \\
& 70 \% \text { of Return of S\&P } 500 \\
\text { Minimum Return }=(A+B) / 2\end{array}$ & 36 months & Quarterly & $\begin{array}{l}\text { Full disclosure } \\
\text { after } 30 \text { days }\end{array}$ \\
\hline Chile & $\begin{array}{l}\text { Risky funds }= \\
\text { Min }(50 \% \text { of ARS, ARS - } 4 \%) \\
\text { Conservative funds }= \\
\text { Min }(50 \% \text { of ARS, ARS }-2 \%)\end{array}$ & 36 months & Monthly & $\begin{array}{l}\text { Full disclosure } \\
\text { after } 10 \text { days }\end{array}$ \\
\hline Uruguay & Min $(2 \%$ real, ARS - $2 \%)$ & 12 months & Monthly & \\
\hline Poland & $\operatorname{Min}(50 \%$ of ARS, ARS - 4\%)* & 36 months & Bi-annually & $\begin{array}{c}\text { Full disclosure yearly; } \\
\text { Partial } 2 \text { x year }\end{array}$ \\
\hline
\end{tabular}

Source: SBC, SAFP, KNUiFE.

* Weights have a 15\% cap and shares of remaining funds are increased proportionally to reach $100 \%$.

ARS: Weighted Average Return of the System; RSP: Return of the Synthetic Portfolio; BVC index: Bogotá Stock Exchange index.

64. At the same time, the main risk of using the relative return as the benchmark is that pension fund portfolios may be driven toward inefficient equilibriums or inefficiency traps which become difficult to overcome ${ }^{26}$ While Polish regulators have adopted a flexible approach towards the MRG, the benchmark is based exclusively on the weighted average of the system, which may result in inefficiency traps. For example, during the nineties, Chilean pension funds increased their equity portfolio to 32 percent of total assets, of which 80 percent in the energy sector. The concentration in one sector of the economy was mainly due to large unexpected capital gains. Each pension fund had to evaluate whether deviations from the benchmark increased the risk of triggering the MRG, and in most of the cases they decided to stick with that risky portfolio. The situation was only solved by a buyout of shares by large strategic investors, allowing all pension funds to reduce their participation proportionately.

65. The high proportion of fixed-income instruments with relatively short durations also suggest that pension fund managers have operated with short investment horizons than the optimal. In Poland and other countries, pension funds hold relatively large amounts of short and medium-term nominal government instruments, in order to avoid exposure to short term volatility due to interest rate fluctuations and low short-term returns. However, this strategy may not be optimal for a long-term investor as it implies exposure to reinvestment risk. ${ }^{27}$

66. Some countries have adopted combined benchmarks as an attempt to solve these traps and lengthen investment horizons. As shown in Table 17, the MRG in

\footnotetext{
${ }^{26}$ Walker (2006) Financial Aspects of the Pension system. Catholic University of Chile. Draft.

${ }^{27}$ Campbell and Vicera (2001) suggest that the risk free asset for pension funds is a long term inflation indexed instrument. In a context of changing real interest rates, nominal bonds with relatively short durations become a risky asset because pension funds are exposed to reinvestment risks.
} 
Colombia is based on a benchmark that combines a synthetic portfolio and the weighted average return of the system. The greater diversity of pension fund portfolios in Colombia may be partly explained by the incentives given in the $\mathrm{MRG}^{28}$

\section{The payout phase}

67. The payout phase of the second pillar has not been designed yet. The lack of an institutional and regulatory framework for the payout phase is cause for some concern, as the workers enrolled in the new system will start retiring in 2009. Although policymakers still have a "grace period" of two years this is hardly sufficient, considering the wide range of options that seems to be under consideration, including the number of providers and the range of products. Moreover, a successful payout phase may also require access of providers to adequate financial instruments to manage their risks, such as indexed fixed-income instruments with very long durations and derivatives. These markets still need to be further developed.

\section{B. An Overview of the Supervisory Framework}

68. The Insurance and Pension Funds Supervisory Commission (KNUiFE) is the body responsible for the supervision for the pension and insurance industry. KNUiFE was created in 2002 from the merger between the State Office for Insurance Supervision (PUNU) and the Pension Fund Supervisory Office (UNFE). The Board of the Commission consists of five members, three of them appointed by the government, one by the Securities and Exchange Commission and one by the Office of Competition and Consumer Protection. The Chairman of the commission is appointed for a five year term.

69. KNUiFE seems to have enjoyed operational autonomy in practice, but does not have the power to issue binding secondary regulation. Secondary regulations have been issued through a limited number of Decrees. KNUiFE does not provide interpretations of the law through guidelines or recommendations and the rationale for its sanctions has not been sufficiently elaborated. There are a number of areas where the law does not provide detailed guidance and further interpretation might be necessary, such as corporate governance of companies in the portfolios of pension funds.

70. Supervisory procedures seem appropriate for the moment but could prove inadequate in the future, as the pension system grows in size and sophistication. KNUiFE has followed a traditional, compliance-based approach to supervision and has been able to monitor the industry in its early stages of development. The pension supervision department has 21 professionals in charge of supervising 15 PTEs. Off-site supervision entails the analysis of a substantial amount of information daily provided by the pension funds, and also provides the basis for the on-site inspections. At the same time, KNUiFE has not yet made sufficient progress in migrating to an approach that is more preventive, promoting sound risk management and internal control systems in the

\footnotetext{
${ }^{28}$ Rudolph, Cheikrouhou, Rocha, and Thorburn (2006).
} 
PTEs. Nor has it developed internal risk scoring systems that would allow it to identify more clearly the areas of higher risk and allocate its resources more effectively.

\section{The Domestic Capital Market}

71. The Polish capital market is dominated by the markets for government securities and the equity market. The markets for privately issued fixed-income instruments are extremely small. As shown in Table 18, the stocks of traded government debt and market capitalization amount to 33 and 32 percent of GDP, respectively, while the stocks of other instruments are negligible. Pension funds hold 18 percent of the overall stock of traded government debt, 9 percent of the stock of equity, and negligible shares of the stocks of other instruments. The very small investments in these instruments are at least partly related to their limited supply and very low liquidity.

Table 18. Stocks and Holders of Financial Instruments, 2005

\begin{tabular}{l|cccccc}
\hline & $\begin{array}{c}\text { Government } \\
\text { Debt }\end{array}$ & $\begin{array}{c}\text { Municipal } \\
\text { Bonds }\end{array}$ & $\begin{array}{c}\text { Corporate } \\
\text { Bonds }\end{array}$ & Equity & $\begin{array}{c}\text { Venture } \\
\text { Capital }\end{array}$ & $\begin{array}{c}\text { Mortgage - } \\
\text { Related Bonds }\end{array}$ \\
\hline Total as \% of GDP & $\mathbf{3 2 . 2}$ & $\mathbf{0 . 3}$ & $\mathbf{0 . 8}$ & $\mathbf{3 1 . 9}$ & $\mathbf{0 . 1}$ & $\mathbf{0 . 1}$ \\
\hline Shares of Total & & & & & & \\
Pension funds & 17.6 & - & 1.7 & 8.6 & - & - \\
Insurance Companies & 17.1 & 2.0 & 7.8 & 1.1 & - & 1.2 \\
Investment funds & 9.3 & - & 16.2 & 5.1 & - & 0.0 \\
Banks & 22.8 & 75.6 & 35.7 & 0.2 & - & 55.0 \\
Other Fin. Intermediar. & 2.4 & 4.4 & 6.0 & n.a. & - & 16.1 \\
Retail & 5.4 & - & 6.9 & 5.9 & - & 0.0 \\
Corporates & 2.1 & 2.9 & 25.5 & 7.7 & - & 0.3 \\
Foreign investors & 22.1 & 13.7 & - & 49.4 & 99.9 & 26.9 \\
Other/non-identified & 1.0 & 1.4 & 0.2 & 22.0 & 0.1 & 0.5 \\
Total & 100.0 & 100.0 & 100.0 & 100.0 & 100.0 & 100.0 \\
\hline Souce: NBP, Fitch Po.
\end{tabular}

Source: NBP, Fitch Polska.

\section{A. The Market for Government Debt}

72. The government has made progress in developing a deep and liquid government securities market, with some success in lengthening the maturity structure and establishing liquid benchmarks around the yield curve. Since 1999, the Polish government has been implementing a consistent debt management strategy aiming at reducing foreign currency risk, increasing average maturity, reducing refinancing risk, and improving market liquidity of domestic debt. ${ }^{29}$ In the domestic segment, the government was able to reduce the relative weight of the T-bills (from 12.7 percent in 2003 to 5.5 percent in 2005) and resume the issuance of longer term fixed rate instruments, building liquidity in the five year fixed rate benchmark bond and to a lesser degree in the 10 year bond. The streamlining of the benchmarks ${ }^{30}$ and the introduction of

\footnotetext{
${ }^{29}$ The risk management analysis done by the Financial Assets and Liabilities Department of the MoF, is in line with good international debt management guidelines (issued by the WB/IMF and the OECD).

${ }^{30}$ Reductions in the number of issues and increases in the size of each issue
} 
the PD system in 2002 played a key role in increasing the liquidity of the government bond market. ${ }^{31}$ Trading is concentrated in the traditional OTC market ( 96 percent of total turnover in 2004). However, the government has issued only one inflation indexed debt, which is relatively illiquid and it is mostly held by foreign investors.

\section{In December 2005, about 78 percent of government debt was held by} domestic investors, but instruments with longer maturities were primarily held by foreign investors. The average duration of the portfolios of domestic investors is only 2.87 , lower than the average duration of 3.86 of the overall stock. As shown in Figure 18, pension funds have made only a modest contribution to the development of this market, holding a portfolio of government securities with relatively short duration (3.07). A similar situation can be found in other countries with young second pillar (e.g., Colombia, Hungary). Defined contribution pension funds in systems that allow switching seem to operate with relatively short investment horizons and to avoid being exposed to interest rate risks. Most of the demand from long-term securities, including inflationindexed securities has come from defined benefit pension funds and insurance companies in Western Europe.

Figure 18. Duration of Government Bonds by Holder

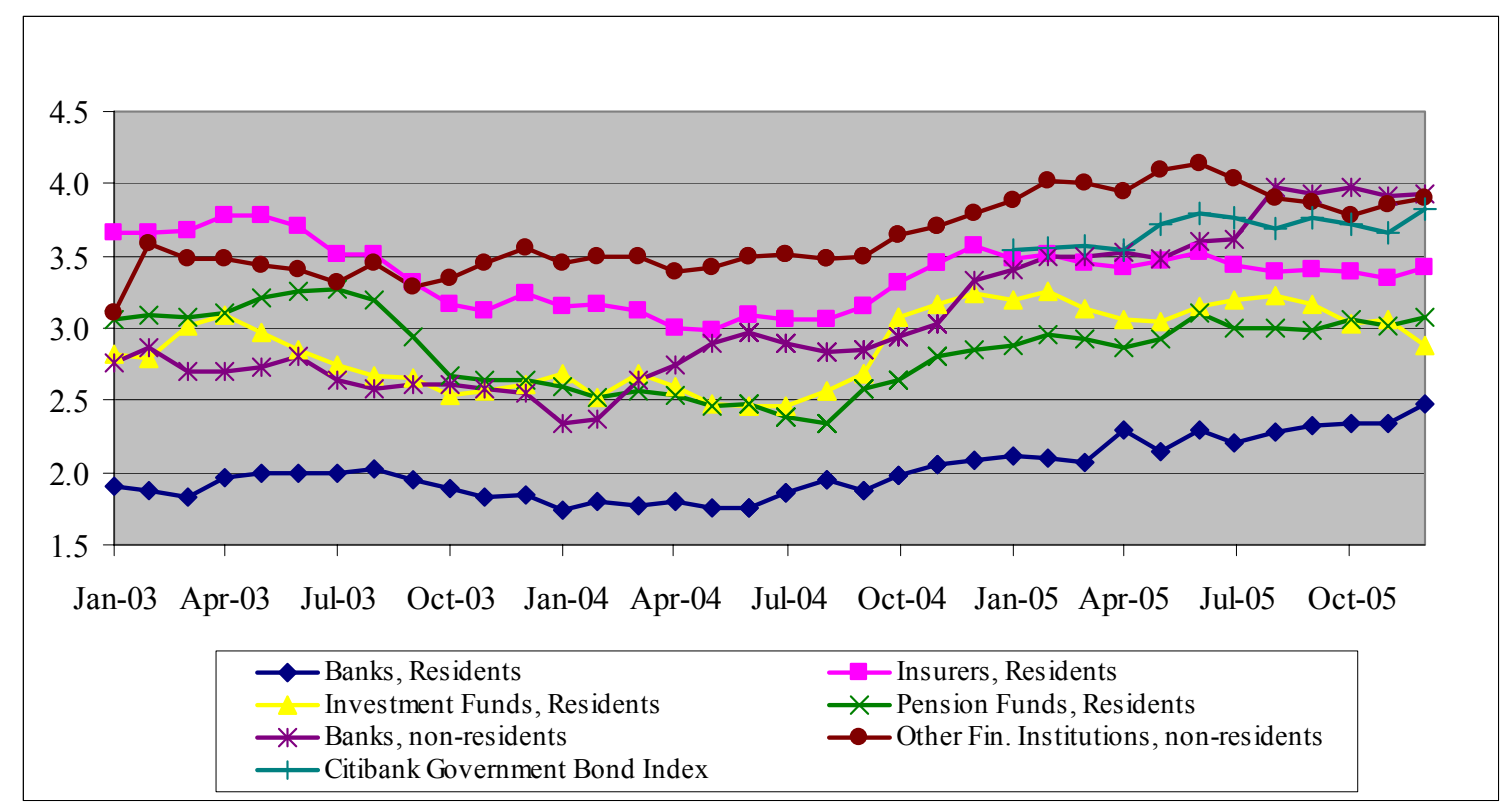

Source: NBP.

\section{B. The Equity Market}

74. The equity market has been increasingly actively in the last three years, and 68 IPOs have taken place between 2004 and 2005. The equity market has experienced an important level of development in recent years, measured not only by the main market

\footnotetext{
${ }^{31}$ The liquidity ratio increased from 0.5 in 2000 to 1.5 in 2004 and the prevailing yield spreads narrowed significantly to $2-3 \mathrm{bps}$ and 5-10 bps in the five and ten year T-bonds, respectively
} 
indicators (number of listed companies, increase in prices and market capitalization, turnover ratios) but also through the impressive amount of IPOs that have taken place in the last two years (36 in 2004 and 32 in 2005). The success in developing private IPOs is the result of an interesting combination of successful exit sell-offs done by private equity funds operating in Poland, a large number of new issuers by private mid-cap companies and the appearance of foreign issuers in the local market (five in 2004 and seven in 2005), that have taken advantage of the liquidity in the local market to raise capital.

75. The elevated activity of the Polish private equity industry has been an important pillar to the success of the public equity markets in Poland, but it is still very small by EU standards. About 30 private equity funds operate in Poland, managing investments of about Euro300 million, and funded mostly from foreign investors. The industry has benefited from a strong exit market, dominated by trade sales and IPOs - more than 350 investments amounting to Eurol.8 billion have been divested since 1990. In recent years, investments have been concentrated on buy-outs, replacement capital and expansion of mature companies (as opposed to smaller start-ups) which is also explained by the dominant role of foreign investor in this industry. This bias has resulted in the evolution of private equity funds towards larger and less risky transactions.

\section{Other Fixed-income Instruments}

\section{Municipal Bonds}

76. General obligation bonds issued by sub-national entities have grown in recent years, but the stock is still very small. Revenue bonds could become an attractive asset class for institutional investors in the future. Given that local governments and their corporations are responsible for undertaking a large share of the investments required to meet Poland's commitments under the EU Accession Treaty, the development of a municipal bond market could play a critical role in mobilizing the domestic counterpart of EU cohesion and structural grants associated with these investments, in addition to financing regular investments by sub-national entities. The financing of these projects will involve important grants from EU and loans from the European Investment Bank at concessional interest rates, but the domestic capital market may play a role in the areas that are not covered by official institutions. Some General Obligations bonds have been issued at the market at relatively narrow spreads and have been mostly purchased by banks. In December 2005 there was a successful revenue bond flagship issue that may attract the interest of institutional investors for future issuers.

\section{Corporate Bonds}

77. The lack of development of the corporate bond market is mainly explained by current market conditions, including the relatively low investment ratio and the high liquidity of the corporate sector. However, there may also be institutional and regulatory factors constraining the market. The lack of development of the corporate bond market can be partly explained by macroeconomic factors and the universal banking system that Poland has adopted - universal banks with excess liquidity may have little interest in developing a new business that competes with their core business. However, 
the current financial architecture does not promote the development of this instrument either. For example, there is lack of regulation on minimum disclosure requirements for issuers, deficiencies in the depository functions (securities do not need to be deposited at the National Depository of Securities), and lack of a culture of risk ratings. These factors may limit trading and the interest of institutional investors in this market.

\section{Mortgage-backed Securities (MBS)}

78. The market for mortgage bonds and mortgage-backed securities is extremely small, but could have a positive development in the near future due to the recent growth of the pool of housing loans. With the important economic recovery and the growth in house sales and mortgage loans, there could be a positive outlook for the future development of the mortgage bond market in Poland. With the large growth of the mortgage portfolio and the need for banks to better manage their financial risk exposures created by this new asset class, there will be a growing interest in the near future to use instruments that could provide new funding and better risk management. Initially priority should be given to covered bonds over more complex securitization schemes, given the preconditions and the complexity of the reforms needed to make the latter work properly.

\section{ReCOMmEndations FOR IMPROVIng The PERformance OF THE SECOND PILlaR}

\section{A. Recommendations for Improvements in the Accumulation Phase}

\section{Market Structure, Competition, and Fees}

79. The government should consider a more accommodative policy for future mergers of pension funds. The attempts to promote competition in returns and avoid concentration through a lottery that allocates new entrants to smaller and high performing funds may not yield good results when fees are reduced further, because smaller funds may not have sufficient scale to operate profitably. Moreover, the larger pension funds may simply offset the effect of the lotteries with more intensive marketing. It may prove difficult to implement strict price controls and avoid concentration at the same time, under the current institutional arrangements. Therefore, if the current schedule for fee reductions is implemented it may be necessary to allow some PTEs to merge in order to gain scale and reduce costs. Moreover, if the government decides to pursue its policy of strict price controls it will need to consider regulating more extensively the pension business, preventing loss of quality in portfolio selection, risk management and services to the public. ${ }^{32}$

80. If the government decides to continue pursuing the policy of promoting competition in returns while reducing fees further, it may need to consider more

\footnotetext{
${ }^{32}$ The reduction in the caps on fees to low levels may lead PTEs to reduce the quality of their services and operations in order to protect their profit margins. The experience with price regulation of private monopolies indicates the need to extend regulation to many areas of the business and impose minimum performance targets to protect consumers.
} 
structural changes in the second pillar, along the lines of the Swedish model. ${ }^{33}$ In this model all basic services are centralized, including the management of individual accounts. The central provider operates like a central clearing house and outsources asset management to a large number of investment funds. Individual account holders can select freely among the licensed asset managers. The accounts are "blind" - individuals can select the asset manager, but the asset managers do not know the individual identity of their customers. They simply receive from the central account manager a total volume of funds to manage. Blind accounts eliminate any incentive to engage in expensive direct marketing tactics and focus competition on returns.

81. If the Swedish model is favored, it would be important to address some of its potential weaknesses. The central provider would need to be properly regulated and supervised. To avoid an excessively large number of funds regulators would need to maintain proper licensing requirements, possibly including the payment of a basic licensing fee. The system should include a well designed default fund for passive new entrants. Finally, there should be an effort to maintain a minimum level of communication and information with members and should promote that contributors select asset manager free from employers intervention.

82. The ownership links between pension funds and insurance companies and the existence of common contractual arrangements opens room for crosssubsidization within the group. Pension funds and insurance companies share the same administration companies and also have contracts with the sales force of insurance companies. While these arrangements may allow both institutions to explore economies of scale effectively, they also open room for price transfers. It would seem important for KNUiFE to introduce procedures that verify if the prices of these arrangements are in line with market prices.

\section{Investment Regime}

83. Authorities may consider reviewing the investment regime in order to promote greater portfolio diversification of pension funds. Greater responsibility should be given to PTEs in defining investment policies. There are various elements in the investment regulation of pension funds that need to be reviewed, including the limits on foreign investment, corporate bonds and bond issued by non public companies. These changes should be accompanied by the introduction of minimum standards of internal risk management and controls.

84. The limit on foreign assets should be raised to a meaningful level, allowing pension funds to diversify more effectively their risks. The most important objective should be to increase net, risk-adjusted returns of pension fund members. In addition to raising the statutory limits on foreign assets, regulators should also review current fee restrictions as these may also detain foreign investments. For example, regulators may consider allowing PTEs to net fees on foreign investments from returns, while imposing

\footnotetext{
${ }^{33}$ See Palmer (2005).
} 
caps to prevent abuse. Authorities should also consider allowing pension funds the use of foreign exchange forwards and futures as a mechanism to hedge currency positions.

85. The authorities should consider relaxing the limits on unsecured plain vanilla corporate bonds while promoting the use of credit ratings. The limit for investment in unsecured corporate bonds issued in the public market should at least be comparable the limit for investment in equity, although under this limit only rated instruments should be eligible for pension funds. Regulation may also consider increasing the limit for non public bonds when these instruments are properly rated.

86. Pension funds should be authorized to commit resources in closed-end investment funds. Since investment fund's fees can be deducted from returns of these instruments, pension funds may consider in the future utilizing more intensively investment funds to circumvent the caps on pension funds' fees. The current regulation does not contemplate commitment of funds, which is the usual practice for investments in closed-end investment funds. Countries such as Chile have already allowed pension funds to commit resources to investment funds, which is the usual practice in the private equity industry. Quotas or shares of private equity and venture capital funds are attractive instruments to pension funds, as they usually provide long maturities with very high yields. Closed-end investment funds are the ideal vehicles for investments in private equity and venture capital, because they combine financial resources with management capacity (provided by the general partner of the closed-end investment fund). Management and other fees paid to closed-end investment fund managers can be deducted from pension fund returns and pension fund fees are capped by regulation. As fees become tighter since the cost to the pension asset manager is zero, pension funds may invest more intensively through closed-end investment funds. In the case of Chile, after a period of unusually high fees paid to investment fund managers, the government decided to impose caps on these fees to prevent abuse. ${ }^{34}$ Private equity funds usually charge a management commission of about 2.5 percent of the fund, which covers the cost of running these investments.

\section{The authorities should consider introducing a number of additional} portfolios, possible combined with a default portfolio for passive members. The current system assumes that there is a single portfolio that fits the interests of all the contributors, but a system with more portfolios may meet more effectively the needs of contributors with different risk-return preferences. If portfolio choice is introduced, it should be accompanied by a default rule for contributors who do not choose a particular portfolio. The default could involve lifecycle or "no lose" portfolios (capital protection). ${ }^{35}$ The need for more portfolios will become more apparent as the payout phase approaches, as it is not appropriate to expose retiring workers to the risk of wide fluctuations in equity prices or interest rates. Older contributors should have portfolios relatively immunized to equity and interest rate fluctuations with a closer resemblance to the portfolios of annuity providers. ${ }^{36}$ The introduction of portfolio choice should also be

\footnotetext{
${ }^{34}$ In the Chilean model, pension fund fees are not capped.

35 See, e.g., Poterba et al (2006).

${ }^{36}$ See Rocha and Thorburn (2006), Booth and Yakoubov (1998), and Walker (2003).
} 
accompanied by efforts to improve financial education and the flow of information to members.

\section{Minimum Return Guarantee}

88. The government should consider introducing a synthetic portfolio in the definition of the benchmark for the calculation of the MRG. The current benchmark is based exclusively on the average return of the system and may create inefficiency traps which are difficult to overcome. For example, the fixed-income portfolio of pension funds has a shorter duration than the portfolios of other institutional investors, and may not be optimal from a long-term perspective. The synthetic portfolio should be designed by a group of independent advisors in order to avoid conflicts of interest and political interference in portfolio allocation.

\section{Valuation and Trading Rules}

89. KNUiFE will need to improve valuation rules as portfolios become more diversified. Most transactions with fixed-income instruments are conducted in OTC markets, where prices are not transparent. This has not been a problem for the time being, as government securities account for the bulk of the fixed-income portfolio and there is some liquidity along the yield curve. However, the lack of detailed valuation rules could pose a problem in the future, as pension funds start investing in less liquid instruments and are allowed to use derivatives. This is an issue that goes beyond the pension fund system, as other institutional investors, such as investment funds, have different valuation systems. The government should promote a single system of valuation for all institutional investors whose portfolios are marked to market, including pension funds, banks and investment funds. In the meantime, KNUiFE should consider moving toward a single price for each instrument at each moment of time.

90. The government should provide a solution to the current practice of allowing pension funds to operate through a non transparent OTC market by requesting enhancement in the level of transparency of these OTC markets or by forcing pension funds to operate exclusively though electronic trading platforms. Although countries like Chile and Colombia have opted for requesting pension funds to operate only through formal exchanges or electronic trading platforms, it is possible to achieve the same results, but with greater flexibility, if the levels of transparency and disclosure of the OTC market are sufficiently enhanced.

\section{Supervisory Practices}

91. KNUiFE should provide interpretations of the law through guidelines or recommendations and the decisions underlying sanctions should be sufficiently elaborated. There are a number of areas where the law is not precise enough and further interpretation might be necessary. For example, interpretations of the professional secrecy obligations imposed in the Pension Act may contradict the principles of the Tender Offer Law regarding voting at shareholder's meetings. The current uncertainties have created incentives for conservative behavior by PTEs that may have resulted in poor 
monitoring and lack of efficiency in the voting process. Clarification of the boundaries of the law is a necessary step. ${ }^{37}$ KNUiFE may also consider elaborating on the resolutions and sanctions to PTEs in order to create some jurisprudence for the industry.

92. Authorities should consider adopting a supervisory approach that emphasizes sound internal risk management. KNUiFE follows a supervisory approach that is excessively compliance-based and does not promote sound internal risk management. Some PTEs seem to be strengthening risk management systems, but this is due to an internal policy of the group and not to regulatory requirements. It is important to ensure minimum standards of risk management and internal controls in all institutions, especially as portfolios become more diversified, and new risks emerge. Although the risk of insolvency is low in a defined contribution system (limited to compliance with the MRG), it is important to ensure that pension funds operate at the efficient frontier and do not expose members to unnecessary risks. As a first step, KNUiFE may consider requiring external auditors to evaluate the quality of internal risk management and controls against recognized standards such as COSO and COBIT. ${ }^{38} \mathrm{KNUiFE}$ may also need to build capacity in order to adopt risk-based supervision.

93. Authorities should consider increasing the levels of transparency of ZUS, including periodical evaluations by external auditors about the quality of internal control management. It would be useful for the resource management efficiency of pension funds to be able to provide greater predictability to monthly contributions and to shorten the period that resources remain in ZUS.

\section{B. Preparing the Regulatory Framework for the Payout Phase P $^{39}$}

\section{The development of the regulatory framework for the payout phase will} entail decisions on institutional arrangements (e.g., single versus multiple providers); the development of regulations for retirement products (e.g., the menu of retirement products, marketing regulations), and the development of regulations for providers (e.g., investment, valuation, and capital rules). Polish policy-makers seem to be considering a variety of alternative constructions and would benefit from an assessment of the performance of payout arrangements in other countries with large second pillars, including Australia, Chile, Denmark, Sweden and Switzerland.

95. Australia has adopted a decentralized model with multiple providers and a very liberal approach to product regulation, allowing lump-sums, phased withdrawals with defined terms, and several types of annuities. The degree of annuitization has been extremely low, with most retiring workers taking lump-sums and

\footnotetext{
${ }^{37}$ Additionally, KNUiFE may also consider requesting each PTE to define a general policy for voting in shareholders' meetings.

${ }^{38} \mathrm{COSO}$ and COBIT are control frameworks used to assess financial processes and IT systems. External auditors of pension funds in Chile and other countries utilize these standards to evaluate the quality of risk management systems and internal controls. Further details can be found in www.sox-online.com.

${ }^{39}$ The recommendations for the payout phase are broadly in line with those in World Bank (2003), while covering some gaps, especially in the area of risk-sharing arrangements and actual country experiences.
} 
to a lesser extent phased withdrawals. ${ }^{40}$ One of the main lessons from the Australian case is that unrestricted access to lump-sums leads to a very low degree of annuitization, in line with the experience of other countries with voluntary systems. This outcome reflects at least to some extent consumer myopia and may not be desirable from a social policy perspective. Even considering the existence of a first pillar in Poland, a large preference for lump-sums would raise the risk of inadequate pensions at old age, especially among middle and low income retirees, and excessive recourse to the minimum pension guarantee, with adverse impact on government expenditures.

96. Chile has adopted a decentralized model that has worked generally well. Policy-makers have adopted a careful but evolving approach to product regulation and also a sound regulatory framework for providers. Policy-makers have also made efforts to develop the necessary financial instruments for providers to manage their risks. ${ }^{41}$ The Chilean market for retirement products has worked generally well and provides a useful reference for Poland. The restrictions on the menu of retirement products are reasonable, contributing to a high degree of annuitization, while also providing some room for individual choice. Market transparency has been recently improved through the introduction of an innovative electronic quotation system. The possibility for providers to price annuities freely according to individual risks (including gender-specific risks) and the imposition of a capital rule that penalizes mismatches have both contributed to financial soundness.

97. Denmark has adopted a decentralized model with extensive risk-sharing arrangements. The Danish system has operated reasonably well, but demonstrates the complexities of regulating risk-sharing arrangements when these are provided by profit-oriented companies and combine the accumulation and payout phases. ${ }^{42}$ The degree of annuitization has been high, due to restrictions imposed by collective labor agreements and tax rules that discourage lump-sums. Danish institutions have coped well with the potential gender imbalance problem that may result from unisex mortality tables, although this may be partly due to the constraints imposed by collective agreements (which limit the scope for individual selection of providers). At the same time, the Danish case shows the complexities involved in the regulation of risk-sharing arrangements in decentralized and competitive environments, where shareholders and policyholders share the same pool of assets and profits. ${ }^{43}$

98. Switzerland has adopted a decentralized model combined with a more interventionist regulatory approach that includes regulation of annuity prices. The degree of annuitization has been high and the market seems to have operated well for many years, but the failure to adjust annuity prices to market developments may have led some companies to generate losses and avoid the market. ${ }^{44}$ The Swiss

\footnotetext{
${ }^{40}$ Thorburn (2006) provides a detailed analysis of the Australian case.

${ }^{41}$ Rocha and Thorburn (2006) provide a detailed analysis of the Chilean case.

${ }^{42}$ Andersen and Skjodt (2006) provide a detailed analysis of the Danish case.

${ }^{43}$ The Czech third pillar is based on multiple and competing providers that operate on a profit-sharing (or risk-sharing) basis. The model has not worked well and policy-makers seem to be considering a radical reform. See Lester (2006).

${ }^{44}$ Buttler (2006) provides a detailed analysis of the Swiss case.
} 
experience shows the difficulties and risks involved in regulating annuity prices, involving regulation of unisex mortality tables and discount rates. Annuity providers are subject to complex risks, even when they are free to determine the prices of their annuities. A heavy-handed regulatory approach may lead providers to avoid offering annuities and leave the market altogether.

99. Sweden has adopted a centralized, public-managed model for the payout phase, as well as a restricted menu of retirement products involving two types of annuities with risk-sharing features (with-profits and variable annuities). The system seems to have many positive characteristics but has not been sufficiently tested. ${ }^{45}$ The with-profits annuities are priced with a very conservative cohort mortality table and a very low discount rate. The excess of market returns over the discount rate is paid as a bonus in the following year. Retirees taking the variable annuity (which operates like a unit-link product) share all risks, including market, longevity and cost risks. The mortality table used for pricing is less conservative, but mortality experience is reviewed every three years against the table and the benefits are adjusted accordingly. These two types of annuities are very similar to those offered by the TIAA-CREF pension fund for college professors in the US. ${ }^{46}$ The Swedish system has many positive features, including low operating costs due to scale, a large risk pool, and interesting risksharing features in a non-profit environment. The Swedish system shows the greater feasibility of offering risk-sharing products when these are restricted to the payout phase and provided in a non-profit environment. However, the system has not been sufficiently tested, especially its resilience to political interference in pricing and asset management.

100. Polish policy-makers must start preparing the regulatory framework for the payout phase, scheduled to start in 2009. While the design of some areas of regulation requires more analysis and consideration, it may be possible to identify areas where decisions can already be made, such as the menu of retirement products. While the existence of a first pillar opens room for some flexibility in the design of the menu of retirement products, it is important to ensure a reasonable degree of annuitization in order to protect workers against market and longevity risks. One possible solution involves allowing partial lump-sums provided that the remaining balance of the first and second pillars is able to generate an annuity equal to a defined multiple of the minimum pension. In Chile this multiple is 1.5 times the minimum pension, but it could be higher in Poland. At the same time, phased withdrawals may need to be restricted to avoid a segmentation of the risk pool caused by the mandatory use of the unisex mortality table (men would tend to favor phased withdrawals and women would tend to favor annuities). Phased withdrawals could play a role in the case of low income workers with payouts close to the minimum pension - these workers should probably be required to buy PWs, and exhaust their balances before the government starts paying the minimum pension. $^{47}$

\footnotetext{
${ }^{45}$ Palmer (2006) provides a detailed analysis of the Swedish case.

${ }^{46}$ See www.tiaa-cref.org.

${ }^{47}$ This is the approach adopted in Chile and recommended in World Bank (2003).
} 
101. Polish authorities should favor fixed and price-indexed annuities as this is the product that protects workers against the most important risks in the retirement phase, while also allowing other types of annuities. For example, the authorities should consider products such as adjustable annuities, which recalculate payouts every three years or so depending on the movements of long-term interest rates, and also variable annuities on a unit-link basis. These products allow annuitants to share upside gains and simplify the asset liability management of providers, reducing capital requirements and allowing providers to offer better initial payouts. To reduce the room for downside losses, especially for lower income workers, these annuities could be offered in combination with a minimum level of fixed indexed annuities. The authorities should also consider allowing annuities with guaranteed periods as these products reduce the potentially adverse effects of the unisex mortality table (gender imbalances) and provide an element of bequest that can prove very attractive to retiring workers. The authorities may consider imposing joint annuities on married retirees, in order to protect their spouses against longevity risk.

102. The authorities seem to be considering annuities with stronger risk-sharing features such as with-profits annuities and variable annuities that share not only market risks but longevity risks as well. These constructions have attractive features but may be difficult to regulate and supervise in a decentralized and competitive model. Annuities with risk-sharing features address some complex risks effectively and require less capital and reserves from the provider (in some cases no reserves at all), allowing the provider to offer better initial payouts. They have been adopted in non-profit environments (e.g., Sweden, TIAA-CREF in the US), but may be difficult to regulate and supervise in a decentralized and competitive environment. Some providers may offer attractive terms to new annuitants in order to gain market share and subsequently force a drastic adjustment on the whole pool of policyholders in order to restore solvency, thereby generating unfair distributions of wealth across cohorts. Shareholders may appropriate an excessive share of the profits, claiming compensation for excessive equity risk. These are the reasons why these arrangements are not favored in most countries.

103. If the authorities decide to adopt the decentralized model, it would be important to introduce institutional arrangements that contain marketing costs and ensure access of annuitants to the best quotes. The electronic quotation system recently introduced in Chile merits examination, as it has reduced the influence of insurance brokers and ensured access of retiring workers to the best quotes in the market. In order to contain marketing fees the authorities may also consider imposing caps on broker's fees as in the case of Chile, or simply forbidding insurance brokers to charge fees in the case of second pillar annuities, as in the case of Colombia.

104. Providers of annuities are exposed to complex market and longevity risks over long periods of time and need to be properly regulated and supervised. Capital rules that penalize asset-liability mismatches and that address longevity risk effectively are a critical element of the regulatory framework for providers. The Solvency II initiative under discussion will probably include risk-based capital rules that address these risks, but it may be necessary to adapt the overall rules to the risks of the annuity business. It is also important to make faster progress in ensuring sound risk 
management capacity in the institutions and implementing risk-based supervision, in order to ensure a resilient and stable market.

105. Finally, annuity providers will need to have access to proper financial instruments to hedge their risks. Annuity providers will need to manage the complex longevity and market risks associated with their liabilities. Proper asset liability management will require access to a steady supply of indexed fixed-income instruments with long durations, with implications for the design of government debt management strategies in coming years. Access to derivatives and reinsurance will also contribute to efficient asset liability management by providers.

\section{Developing Financial Instruments for the Two Phases}

106. The supply of suitable domestic financial instruments could be significantly expanded by completing the privatization program. The divestiture of government participation in large conglomerates such as the energy sector would expand the supply of suitable assets and enhance secondary activity in the market. This program should include the floating of the remaining shares of the companies that were listed but on which the government still keeps a majority control. This process should be accompanied by better corporate governance standards in state-owned companies, as this will facilitate the transition to listing at the exchange.

107. The government should complete the reforms that bring effective protection to minority shareholders. Pension funds will be one of the most benefited agents, as they are the most important institutional investor in the equity market that in most of the cases acts as a minority shareholder. ${ }^{48}$

108. The government should facilitate the development of the investment fund industry for investments in SMEs. The government may consider reviewing the regulatory framework for the intermediate vehicles (limited joint-stock partnership and closed-end funds) in order to make them attractive to both foreign and local investors. The regulation should ensure a complete pass-trough of taxes to these financial vehicles.

109. It may be necessary to assess in more detail the evolving patterns of demand for government bonds in order to ensure an efficient debt management strategy. Currently, the longer maturities are primarily demanded by foreign investors, while pension funds seem to focus on short- and medium-term maturities. Further lengthening of the yield curve to European standards may result in excessive reliance on foreign investors and eventually increase interest rate volatility. The government should also take into consideration the need for more frequent and larger issues of inflation indexed instruments in the near future, as annuity providers may need these instruments to hedge the risks associated with their liabilities.

110. The government should create conditions for the development of a healthy sub-national bond market in a set of well-coordinated policy measures designed to eliminate moral hazard, improve market transparency, establish a level playing

\footnotetext{
${ }^{48}$ More detailed recommendations are provided in the Corporate Governance ROSC elaborated in 2005.
} 
field on the market, and strengthen asset-liability management by local governments, will need to be implemented. For more details, a recent assessment was presented to the government in a policy note (World Bank (2006)).

111. The development of the corporate bond market will require enhancements in market infrastructure in the areas of custody and depository. Currently the bonds are kept in the custody of the banks. The government should consider requiring that all fixedincome instruments are centrally deposit in the NDS, as this may help enhancing the liquidity of these instruments.

\section{In the area of securitization there are significant regulatory and legal}

impediments that need to be solved. In the case of mortgage-backed securities some of the most important measures include: (i) allow lenders to hold any related securities, including subordinated tranches; (ii) exploring ways to legally lift or facilitate the requirement that certificates cannot be issued until transfer of each lien is registered; (iii) in the case that banks decide to create an SPV joint-stock company, allowing banks to interact with the vehicle. In the case of asset-backed securities the most important measures include: (i) ensuring the tax neutrality of the SPV, (ii) facilitating the transfer of the assets and liens, (iii) ensuring asset segregation in case of the bank's bankruptcy, (iii) writing the detailed rights and duties of the SPV company (capital, debt borrowing and bond issuance, enhancement support, regulations), (iv) adjusting the status of corporate bonds to the specifics of structured finance and differentiated repayment rights, and (v) allowing the acquisition of the issued securities by the selling bank.

113. There is a need to strengthen the enforcement capacity of KPWiG. KPWiG should be granted more authority over issuers and auditors. The agency should consider more reliance on well managed SROs, proper use of check and balance mechanisms (e.g., independent board members, independent audit committee, custodians and trustees), and introducing a risk oriented supervision approach to gain efficiency in the use of the limited resources. 


\section{REFERENCES}

Andersen and Skjodt. 2006. "The Annuities Market in Denmark." Unpublished Manuscript, The World Bank, Washington DC.

Blake, David, Bruce Lehmann, and Allan Timmermann. 2002. "Performance Clustering and Incentives in the UK Pension Industry." Journal of Asset Management 3: 173-194. Also in Financial Markets Group Discussions Paper dp294, London School of Economics.

Bernstein, Solange, and Alejandro Micco. 2002. "Turnover and Regulation: The Chilean Pension Fund Industry.” Documento de Trabajo No. 180. Central Bank of Chile.

Bernstein, Solange, and José Ruiz. 2005. "Sensibilidad de la Demanda con Consumidores Desinformados: El Caso de las AFP en Chile.” Serie Documentos de Trabajo No. 4. SAFP. Chile.

Booth, Philip and Yakoub Yakoubov, "Investment Policy for Defined-Contribution Pension Scheme Members Close to Retirement: An Analysis of the "Lifestyle" Concept," North American Actuarial Journal vol. 4, no. 2.

Buttler. 2006. "The Annuities Market in Switzerland." Unpublished Manuscript, The World Bank, Washington DC.

Campbell, John, and Luis Viceira. 2002. "Strategic Asset Allocation. Portfolio Choice for Long-Term Investors.” Oxford University Press.

Chlon, Agnieszka, Marek Góra, and Michal Rutkowski. 1999. "Shaping pension reform in Poland: Security through diversity." Social Protection Discussion Paper Series No 9923. The World Bank.

Corbo, Vittorio, and Klaus Schmidt-Hebbel. "Efectos macroeconómicos de la Reforma de Pensiones en Chile, in CIEDESS, ed, Resultados y Desafíos de las Reformas a las Pensiones."

Gal R., A. Simonovits, and G. Tarcali. 2001. "Generational Accounting and the Hungarian Pension Reform.” TARKI, Budapest.

IMF and World Bank. 2001. "Guidelines for Public Debt Management."

IMF. 2005. "The Polish Pension Reforms after Six Years.", "Selected Issues: Republic of Poland." Country Report 05/264, July. http://www.imf.org/external/pubs/ft/scr/2005/cr05264.pdf 
Hausner, Jerzy. 2002. "Poland: Security through Diversity." in Martin Feldstein and Horst Siebert, eds. Social Security Pension Reform in Europe, NBER and The University of Chicago, Chicago, III.

Hausner, Jerzy. 2001. "Security through diversity: Conditions for Successful Reform of the Pension System in Poland" in Janos Kornai, Stephan Haggard and Robert Kaufman, eds. Reforming the State. Cambridge University Press.

Kotlikoff, Lawrence. 1995. "Privatization of Social Security: How it works and why it Matters." NBER Working Paper Series 5330 (October).

Kotlikoff, Lawrence. 1996. "Simulating the Privatization of Social Security in General Equilibrium.” NBER Working Paper Series 5776 (September).

Lester, Rodney. 2006. "An Assessment of Corporate Governance Mechanisms of Czech Pension Funds." Unpublished Manuscript, The World Bank, Washington DC.

Marinovic, Ivan, and Salvador Valdés. 2005. "La Demanda de las AFP Chilenas 19932002." Catholic University of Chile. Draft.

Ministry of Labour and Social Policy, 2005, Reply to the Social Protection Committee questionnaire of Minimum Pensions, Warsaw, Poland.

Ministry of Labor and Social Policy. 2006. "Country Fiche: Poland.” Prepared for the Working Group on Ageing of the Economic Policy Committee, Warsaw (February).

Murgasova, Zuzana. 2005. "Post Transition Investment Behavior in Poland: A Sectoral Panel Analysis." IMF Working Paper WS/05/184. http://www.imf.org/external/pubs/ft/wp/2005/wp05184.pdf

OECD. 2005. "Pension at a Glance", Paris.

Palmer, Edward. 2005. “Sweden's New FDC Pension System.” Unpublished Manuscript. The World Bank. Also in Documento de Trabajo 363. Centro de Estudios Públicos. Santiago, Chile (in Spanish).

Palmer, Edward. 2006. “The Annuities Market in Sweden.” Unpublished Manuscript, The World Bank, Washington DC.

Palacios, Roberto, and Roberto Rocha. 1998. "The Hungarian Pension System in Transition.” The World Bank Social Protection Discussion Paper Series No 9805.

Poterba, J., J. Rauh, S. Venti, and D. Wise. 2006. "Lifecycle Asset Allocation Strategies and the Distribution of 401(k) Retirement Wealth." NBER Working Paper No. 11974, (January). 
Rocha, Roberto, and Dimitri Vittas. 2002. "The Hungarian Pension Reform: a Preliminary Assessment." in Martin Feldstein and Horst Siebert, eds. Social Security Pension Reform in Europe. NBER and the University of Chicago Press. Chicago, Ill.

Rocha, Roberto, and Craig Thorburn. 2006. “An Analysis of Money's Worth Ratios in Chile." Policy research Working Paper WPS3926. The World Bank.

Rudolph H., H. Cheikrouhou, R. Rocha, and C. Thorburn. 2006. "Financial Sector Dimensions of the Colombian Pension System." The World Bank, Washington DC.

Thorburn, Craig. 2006. “The Annuities Market in Australia.” Unpublished Manuscript, The World Bank, Washington DC.

Walker, Eduardo. 2003. "Portafolios Optimos Para Los Nuevos Sistemas De Pensiones de Paises Emergentes.” Unpublished manuscript. Catholic University of Chile.

Walker, Eduardo. 2006. "Financial Aspects of the Pension system." Catholic University of Chile. Unpublished manuscript.

World Bank. 2003. "Poland: Multi-Pillar Pension System - Second Pillar Payouts."

World Bank. 2006, "The Polish fixed-income securities market: Recent developments and selected policy challenges." 


\section{Appendix I. An Analysis of Price Competition in the Pension Sector}

In most reforming countries, the demand for pension products has proved inelastic to returns and fees and more responsive to direct marketing. In Poland, there is no evidence that contributors have switched towards pension funds with better performance either. As shown in Figure A1, there is no clear correlation between growth in market shares and the efficiency of pension fund portfolios, as measured by Sharpe ratios. In fact, the three pension funds with lower returns increased their market share between 2000 and 2005.

We tested formally the hypothesis that contributors responded to measures of return of individual pension funds during the 2001-2005 period. The test was conducted regressing switchovers of contributors (transfers of contributors across pension funds) against rates of return and Sharpe ratios of pension fund portfolios in the 2001-2005 period. ${ }^{49}$ The hypothesis was rejected. As shown in Figure A2 and Table A1, these variables are not significant and the predictive power of the model is close to zero. No major differences were found when the model was specified in its first differences and with lags in the measures of return and efficiency. These findings are relatively similar to other reforming countries, such as Chile, where the only significant variable in explaining switchovers of contributors seems to be the size of the sales force. ${ }^{50}$

Figure A1. Sharpe Ratios and Growth in Market Shares

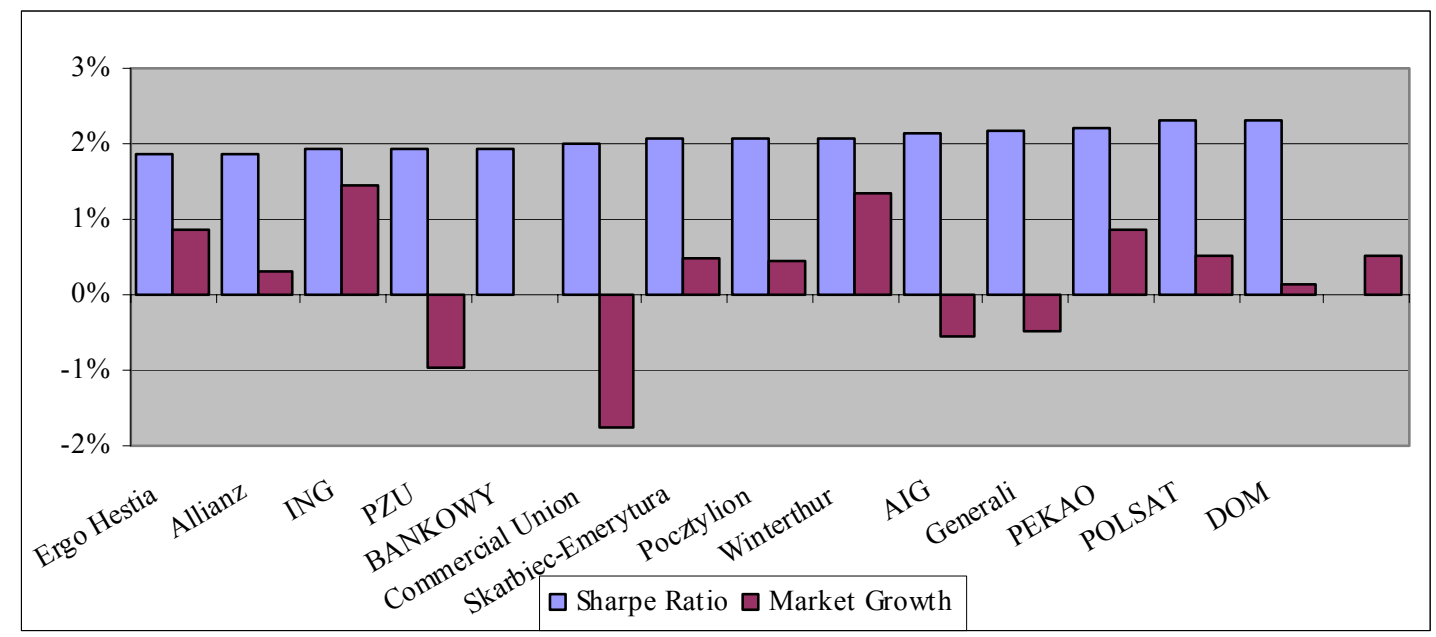

Source: KNUiFE.

Note. Sharpe Ratio is calculated for 2003-2005 and growth in market share is calculated for 2000-2005.

\footnotetext{
${ }^{49}$ As fees are relatively flat among pension funds for new entrants, regressions excluded this variable.

${ }^{50}$ For the case of Chile, Bernstein and Micco (2002), Marinovic and Valdes (2005), and Bernstein and Ruiz (2005) provide econometric analysis of switching patterns, showing that switching of managers is unrelated to measures of performance.
} 
Figure A2. Quarterly Switchovers and OFE's Rate of Return (t-1)

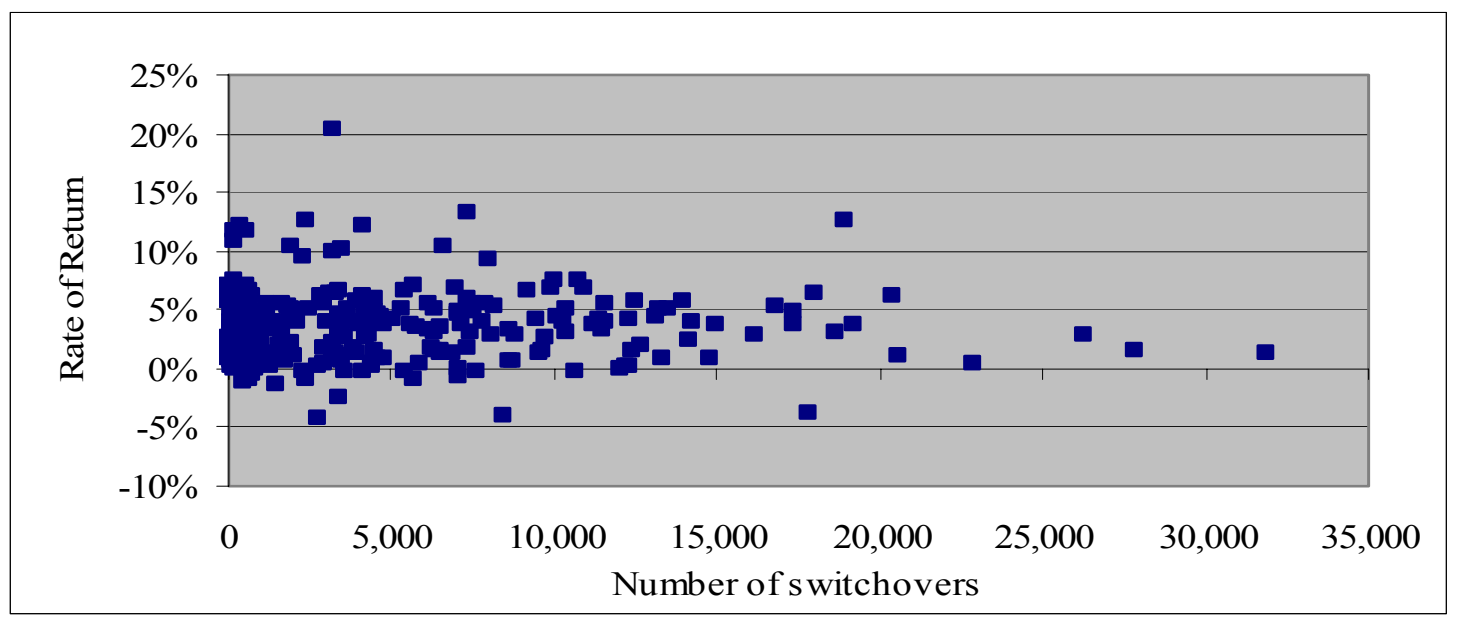

Source: KNUiFE.

Table 19. Panel Data Estimates

Panel Data: 2001-2005, Quarterly Observations

Dependent Variable: Gross switchovers

\begin{tabular}{|c|c|c|c|c|c|c|}
\hline Number of observations & 255 & 240 & 255 & 240 & 255 & 255 \\
\hline Return (t-1) & $\begin{array}{l}-2612 \\
(0.23)\end{array}$ & $\begin{array}{l}-3359 \\
(0.25)\end{array}$ & & & & \\
\hline Return (t-2) & & $\begin{array}{l}-1893 \\
(0.15)\end{array}$ & & & & \\
\hline Sharpe Ratio (t-1) & & & $\begin{array}{c}261 \\
(0.87)\end{array}$ & $\begin{array}{c}296 \\
(0.80)\end{array}$ & & \\
\hline Sharpe Ratio (t-2) & & & & $\begin{array}{c}265 \\
(0.64)\end{array}$ & & \\
\hline $\mathrm{D}$ (Return) & & & & & $\begin{array}{c}-985 \\
(0.14)\end{array}$ & \\
\hline D(Sharpe Ratio) & & & & & & $\begin{array}{c}-59 \\
(0.14)\end{array}$ \\
\hline $\mathrm{R}$ square & 0.0002 & 0.0003 & 0.0030 & 0.0035 & 0.0001 & 0.0003 \\
\hline
\end{tabular}

